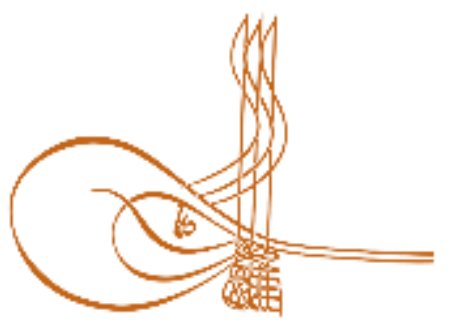

www.turkishstudies.net/turkishstudies
Turkish Studies

eISSN: $1308-2140$

Research Article / Araştırma Makalesi

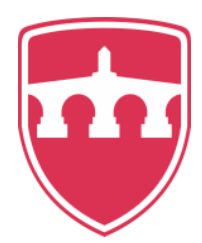

INTERNATIONAL

BALKAN

UNIVERSITY

Sponsored by IBU

\title{
19.yy Başından Cumhuriyetin Kuruluşuna Kadar Olan Süreçte Beyoğlu ve Çevresinde Meydana Gelen Yangınların Galata Sarayı'nın Değişimine Etkileri
}

\author{
The Effects of Fires in Beyoglu and Surroundings on the Structural Change of "Galata Sarayi" \\ from the Early 19th Century to the Establishment of the Turkish Republic
}

\author{
Öykü Bahar Balcı* - Mehmet Sinan Kolay ${ }^{* *}$
}

\begin{abstract}
Galata Sarayı (Galata Palace), later known as Mekteb-i Tibbiye, Mekteb-i Sultani or Galatasaray High School, has undergone many structural changes throughout the history of five hundred years as an educational institution. It is determined that most of these reconstructions occurred due to the fires in the region. The aim of this article, after determining the dates of the fires that affected the building, is to ascertain the construction activities and the structural changes they caused in the building. Since most of the documents dates to the 19th and 20th centuries, the study is limited to the construction activities in this period. First of all, in the scope of the historical process, the historical background of Galata Saray from its foundation to the present day and the fires ocurred in Beyoğlu and its surroundings after 17th century in parallel to the settlement process of Beyoğlu in 17th century have been examined. The construction activities as a result of the fires of 1817, 1831 and 1848 in the region and the 1907 fire occured inside the school, which caused damage to the Galata Sarayı; are analyzed in detail through archival documents, travelers' notes, journals, maps of the period, drawings and old photographs. In the view of the data provided by the sources, the construction activities in the period after the half of the 19th century could be evaluated on a more detailed scale. The greatest change in the structure took place during the reconstruction process in 1862 after the 1848 fire that occurred during the period of Mekteb-i Tibbiye. This situation is in line with Beyoğlu's masonry reconstruction process. The structure was also compared with examples with similar functions and plan schemes in the context of Ottoman architecture under the influence of the West in the 19th century.
\end{abstract}

Structured Abstract: For five hundred years, Galata Sarayı, today known as Galatasaray Lisesi, has been a significant educational institution both in Ottoman and Turkish Republic era. The institution that has been located at the Galatasaray district of Beyoğlu since its foundation. Altough various researches and publications had been carried out on the educational history of Galata Sarayl, no specific research had been done on its architecture. Throughout the history the building had undergone a lot of structural changes. But the most

\footnotetext{
${ }^{*}$ Arş. Gör., İstanbul Teknik ÜniversitesiMimarlık FakültesiMimarlık Bölümü

Res. Asst., Istanbul Technical University/Faculty Of Architecture/Department Of Architecture

ORCID 0000-0003-0873-612X

balcioy@itu.edu.tr

** ORCID 0000-0001-9250-0288

kolaysin@gmail.com

Cite as/ Atıf: Balcı, Ö. B., Kolay, M. S. (2020). 19.yy başından Cumhuriyetin kuruluşuna kadar olan süreçte Beyoğlu ve çevresinde meydana gelen yangınların Galata Sarayı'nın değişimine etkileri, Turkish Studies, 15(1), 31-55. https://dx.doi.org/10.29228/TurkishStudies.39519

Received/Geliş: 29 October/Ekim 2019

Accepted/Kabul: 25 February/Şubat 2020

Copyright $\mathbb{C}$ MDE, Turkey

Checked by plagiarism software

Published/Yayın: 29 February/Şubat 2020

CC BY-NC 4.0
} 
extensive structural changes occured during the reconstruction of the building after the great fires occurred in the region. The aim of this article, after determining the dates of the fires that affect the building, is to ascertain the construction activities that these fires cause in the building and the structural changes that occur as a result of these activities. The study is limited to the construction activities after the fires in the 19th and 20th centuries, the period where most of the original documents can be found.

As the main data of the research; 18th, 19th and 20th centuries maps, drawings, western travelers' notes, newspapers published by the French press in the Ottoman Empire, Ottoman archival sources and secondary resources are surveyed and analized. The archive of the Galatasaray High School is closed to the public therefore it could not surveyed in this study. The maps of Kauffer, Hellert, Huber, Goad and Pervititch show the Galatasaray district in the 18th, 19th and 20th centuries. The detailed plan drawings and photographs of the building dating to 1880-1900 were reached in the Abdulhamit Collection at the archive of Library of Congress. The books of the European travellers that mentioned various architectural descriptions of the building were accessed from the website of Bibliothèque National de France. The documents at the Prime Minister's Ottoman Archives in İstanbul related to Galatasaray were surveyed as well. The French Press, La Turquie's 1868-1869 issues, Levant Herald's 1868 issues are surveyed through the website of Salt Research and Journal de Constantinople Echo de l'Orient's 1846-1848 issues are surveyed through Salt Research and Bibliothèque National de France. The dates have been chosen considering the fires and important dates in the educational history of the institution. Information on the historical process of the Galata Saray1 until the foundation of the Mekteb-i Sultani can be found in the first volume of Fethi İsfendiyaroğlu's Galatasaray History, which is based on Ottoman archival documents. For the historical process after the foundation of Mekteb-i Sultani, Vahdettin Engin's book Mekteb-i Sultani is referred.

The historical background of the Galata Saray1 from its foundation in the late 15th century to the present day shows that the instituion has undergone a lot of functional changes such as a special school in the Ottoman Palace (Enderun Mektebi), madrasa, medical school (Mekteb-i Tibbiye), high school with western education system (Mekteb-i Sultani in Ottoman Period and Galatasaray High School in Repuclic Period). Therefore, the institution preserves its educational character despite of its structural changes.

Beyoğlu had started to be inhabited as the hinterland of the Galata region in the 17th century. From since then, the urban fabric of Beyoğlu had been changed due to the fires from the 17th century to the late 19th century. Cezar stated that the fires which affected Beyoğlu and the surroundings occured in 1811, 1817, 1823, 1831, 1848 and 1870. Among them the most damaging ones are 1817 and 1870 fires. Especially the 1870 fire is mentioned as the Great Beyoğlu Fire, since, almost the whole district was burnt. After this fire the buildings in Beyoğlu started to be reconstructed in masonry technique instead of timber structure. Therefore the main structural material was changed and today's urban fabric of Beyoğlu emerged. Nevertheless, Mekteb-i Sultani was not affected by this fire. However it was damaged by 1817, 1831, 1848 fires of Beyoğlu and by the 1907 fire that started in the school building.

Since there is no physical evidence remained from the former building of the early 19th century, the information about the mass can be obtained from older maps and the architectural description from the travelers' notes. Therefore it was not possible to go into much detail. Galata Saray1 consisted of seperate singlestorey buildings forming a complex with different functions such as rooms for education, a mosque, kiosks. Even the buildings had some masonry parts, the main structural material was wood. After the 1817 and 1831 fires the mass of the building became more compact yet the main plan and function scheme remained similar.

The construction activities in the second half of the 19th century and the early 20th century, is analyzed in a more detailed scale due to the more detailed maps, drawings and old photographs. The greatest change in the structure took place during the reconstruction process in 1862 after the 1848 fire that happened during the period of Mekteb-i Tibbiye. This fire caused the wooden building to burn down completely. The new building has more compact shape and a plan scheme with central atrium and two wings at the front facade. The threestorey building was built with masonry technique. This great change in construction technique is in line with Beyoğlu's masonry reconstruction process. Although the reconstruction aim of the building was not to be used as barracks, it was used as barracks for less than a year after the constructions were ended. When the other barracks buildings of the period such as Taşkışla and Gümüşsuyu Barraks are examined, it is observed that they both have symmetrical plan with inner courtyard and that the new Galatasaray building is similar to this plan scheme. In addition Galatasaray building also has a similar plan scheme with Venetian Palace and French Palace which were built in the same period in Beyoğlu considering two wings protruding on both sides of the

Turkish Studies, 15(1) 
north facade and an inner courtyard. The plan typologies and the eclectic style in all these examples can be described as a reflection of the Western influence in the Ottoman Empire in the 19th century.

Keywords: Galatasaray, Mekteb-i Sultani, Beyoğlu, Pera, Fire.

Öz: Galata Saray1, sonraki isimleriyle Mekteb-i T1bbiye, Mekteb-i Sultani veya günümüzde Galatasaray Lisesi beş yüz yıllık eğitim kurumu tarihi boyunca yapısal anlamda çok sayıda değişiklik geçirmiştir. Bu imar faaliyetlerinin birçoğunun yangınlar sonucu meydana geldiği saptanmıştır. Bu yazının amacı Beyoğlu çevresinde meydana gelen, yapıyı etkileyen yangınların tarihlerini belirleyerek bu yangınların binada hangi imar faaliyetlerine yol açtığını ve bu imar faaliyetleri sonucunda ortaya çıkan değişiklikleri tespit etmektir. Çalışma, en çok özgün belgenin bulunabildiği 19 ve 20. yüzyıl içinde geçirdiği yangınlar sonrasındaki imar faaliyetleri ile sınırlandırılmıştır. Öncelikle, tarihsel süreç kapsamında Galata Sarayı'nın kuruluşundan günümüze tarihsel süreci ile Beyoğlu'nun 17. yüzyılda yapılaşmaya başlamasıyla, 17. yüzyıldan itibaren Beyoğlu ve çevresinde meydana gelen önemli yangınlar incelenmiştir. Bu yangınlar arasından Galata Sarayı'nın zarar görmesine neden olan 1817, 1831 ve 1848 yangınları ile okulun içinde çıkan 1907 yangını sonucu yapının geçirdiği imar faaliyetleri; arşiv belgeleri, gezgin notları, dönemin gazeteleri, dönemin haritaları, çizimleri ve eski fotoğraflar aracılı̆̆ıla tespit edilerek detaylı olarak incelenmiştir. Kaynakların sağladığı veriler doğrultusunda 19. yüzyılın yarısından sonraki süreçteki imar faaliyetleri daha detaylı bir ölçekte değerlendirilebilmiştir. Yapıdaki en büyük değişim Mekteb-i Tibbiye döneminde meydana gelen 1848 yangını sonrasında, 1862 yılındaki yeniden inşa sürecinde olmuştur. Bu durum Beyoğlu'nun kagirleşme süreci ile paralellik göstermektedir. Yapı, 19. yüzyıl Batı etkisinde Osmanlı Mimarisi bağlamında benzer fonksiyon ve plan şemasına sahip örneklerle de karşılaştırılmıştır.

Anahtar Kelimeler: Galatasaray, Mekteb-i Sultani, Beyoğlu, Pera, Yangın.

\section{Giriş}

Yaklaşık 500 yıllık bir tarihe sahip olan, bugünkü adıyla, Galatasaray Lisesi, hem Osmanlı Devleti döneminde hem de Türkiye Cumhuriyeti döneminde önemli bir eğitim kurumu olmuştur. Kurulduğu günden bu yana Beyoğlu'ndaki Galatasaray bölgesinde bulunan kurum, tarihsel süreç içerisinde birçok kez yapısal ve fonksiyonel anlamda değişikliğe uğramıştır. Galatasaray Eğitim Kurumu'nun eğitim tarihi üzerine çeşitli araştırmalar yapılmışsa da mimarisi üzerine yapılan bir araştırma bulunamamıştır. Yapısal anlamda çok fazla değişiklik geçirdiği göz önünde bulundurulduğunda bu çalışmanın literatürde önemli bir yere sahip olacağı düşünülmektedir. Yapının geçirdiği değişikliklerin birçoğunun yangınlar sonucu meydana geldiği saptanmıştır. Bu çalışma kapsamında Beyoğlu çevresinde meydana gelen, yapıyı etkileyen yangınların tarihleri belirlenerek bu yangınların binada hangi imar faaliyetlerine yol açtı̆g 1 ve bu imar faaliyetleri sonucunda ortaya çıkan değişikliklerin tespiti amaçlanmıştır. Bu amaç çerçevesinde 19. yüzyıl başından Cumhuriyet'in kuruluşuna kadar olan süreç, çeşitli kaynaklardan edinilen bilgilerin derlenmesi ile ele alınacaktır.

Konu ile ilgili yapılan araştırmalarda Galatasaray Lisesi arşivinin kullanıma kapalı olması nedeniyle yararlanılamayacağı, faydalanılacak kaynaklar olarak; dönemin haritaları, çizimleri, dönemin batılı gezginlerinin anıları, Osmanlı Devleti’ndeki Fransız basının çıkardığı gazeteler, Osmanlı arşiv belgeleri ve ikincil kaynak olarak nitelendirilen kitaplar tespit edilmiştir. 19. ve 20. yüzy1llarda üretilen Galatasaray bölgesini içeren Kauffer, Hellert, Huber, Goad ve Pervititch haritaları bulunmaktadır. Library of Congress arşivinde bulunan II. Abdülhamit Koleksiyonu'nda Mekteb-i Sultani döneminin 1880-1900 yıllarındaki planlarına ve fotoğraflarına ulaşılmıştır. Yurt dışından İstanbul'a gelen bazı gezginlerin anı yazılarında yapıyla ilgili mimari tasvirlere yer verilmiştir. Bahsi geçen anı kitaplarına Bibliothèque National de France'ın çevrimiçi sisteminden erişim sağlanmıştır. Başbakanlık Osmanlı Arşivi internet sitesi üzerinden 1800 yılı sonrası Galatasaray ile ilgili evraklar tespit edilerek konu ile ilgili olanlar seçilmiştir. Osmanlı Devleti'nde dönemin Fransızca yayın yapan gazetelerinden La Turquie'nin 1868-1869 yılı sayıları, Levant 
Herald'ın 1868 y1lı sayıları Salt Araştırma'nın internet sitesi üzerinden; Journal de Constantinople Echo de L'Orient'ın 1846-1848 yılı sayıları Bibliothèque National de France ve Salt Araştırma'nın çevrimiçi katalogları üzerinden taranmıştır. 20. yüzyıl için Milli Kütüphane'ye bakılmış ve burada yer alan Galatasaray ile ilgili süreli yayınlar incelenmiştir. Galata Sarayı'nın, Mekteb-i Sultani'nin kuruluşuna kadar olan tarihsel sürecine dair bilgilere özellikle Osmanlı arşiv belgelerine dayanarak hazırlanan Fethi İsfendiyaroğlu'nun Galatasaray Tarihi adlı kitabının birinci cildinden ulaşılabilmektedir. Mekteb-i Sultani'nin kuruluşundan sonraki tarihsel süreç için Vahdettin Engin'in Mekteb-i Sultani adlı kitabından yararlanılmıştır.

Konu, Galata Sarayı'nın Tarihsel Süreci, Beyoğlu ve Çevresindeki Önemli Yangınlar, 1817 Yangını, 1831 Yangını ve Yangın Sonrası 1838 Yılında Mekteb-i Tibbiye'nin Kuruluşu, 1848 Yangını ve Yangın Sonrasında 1868 Mekteb-i Sultani'nin Kuruluşu, 1907 Yangını ve Değerlendirme ve Sonuç olarak yedi başlık altında incelenmiştir. İlk iki bölümde Galata Sarayı'nın tanıtımı, ilk kurulduğu günden günümüze kadar geçirdiği tarihsel süreci ve Pera bölgesindeki önemli yangınlardan genel hatlarıyla bahsedilecektir. Yapının geçirdiği yangınlar bölümlerinde belirtilen tarihlerde gerçekleşen yangınlar; belgeler (anılar, gazeteler ve diğer basılı kaynaklar) 1şığında aktarılacaktır. Galata Sarayı'nın geçirdiği imar faaliyetleri döneminin haritaları, çizimleri ve mimari tasvirleri, etki eden yangınların öncesi ve sonrasındaki durumlar karşılaştırılarak ele alınacaktır. Sonuç olarak bu çalışmada 19. yüzyıl ve 20. yüzyıl cumhuriyet öncesi dönemde yapıya etki eden yangınlar sonucu binanın geçirdiği mimari değişimlerin tespiti amaçlanmıştır.

\section{Galata Sarayı'nın Tarihsel Süreci}

II. Bayezid döneminde (1481-1512) günümüz Beyoğlu bölgesi boş arazilerden, bağlar ve bahçelerden oluşmaktadır (Şekil 1). Padişah II. Bayezid saltanatının ilk yılında, 1481 senesinde bir av gezisi dönüşü Beyoğlu sırtlarından Tophane'ye doğru inerken söylentiye göre Gülbaba adlı bir ihtiyarla karşılaşmıştır ve onunla yaptığ 1 sohbet sonucu ihtiyar II. Bayezid'den bu bölgede bir mektep kurulmasını istemiştir. Böylece Galata Sarayı adı altında saray ve devlet hizmetlerine insan yetiştirmek amaciyla bir enderun mektebi kurulmuştur (Engin, 2016: XXIII). İsfendiyaroğlu, Enderun Tarihçisi Tayyarzade Ata'yı referans göstererek mektebin, on yedi bin metrekareden fazla bir alanda; iki yüz kişilik üç koğuş, cami, hastane, mutfak ve hamam yapılarından oluşacak şekilde inşa edildiğini ifade etmiştir (İsfendiyaroğlu, 1952: 101).

Yavuz Sultan Selim (1512-1520) ve Kanuni Sultan Süleyman zamanında (1520-1566) Galata Sarayı Mektebinde kurallı bir eğitim sistemi kurulmuştur. II. Selim zamanında (1566-1574) Galata Sarayı'ndaki enderun mektebi kısmen Eski Saray'a nakledilerek, boşalan yerlerde bir medrese kurulmuştur. III. Murat döneminde (1574-1595) enderun mektebi yeniden Galata Sarayı'na taşınmışsa da, I. Ahmed devrinde (1603-1617) enderun mektebi yeniden Eski Saray'a nakledilerek Galata Sarayı tekrar medrese haline getirilmiştir. II. Osman devrinde (1618-1622) Galata Sarayı'ndaki öğretim bir daha değişikliğe uğrayarak tekrar saray mektebine dönülmüştür. IV. Mehmed devrinde (1648-1687), Köprülü Fazıl Ahmed Paşa'nın emriyle Galata Sarayı yine medreseye çevrilmiştir. Böylece Kanuni Sultan Süleyman devrinden III. Ahmed devrine kadar olan süreçte Galata Sarayı'nın birçok değişikliğe uğrayarak dönem dönem ihmal edildiği söylenebilir. III. Ahmed devrinde (1703-1730) Galata Saray1 yeniden onarılıp, komplekse bir kasır eklenerek tekrar mektep haline getirilmiştir (K1lıçoğlu vd., 1971: 911-912). 


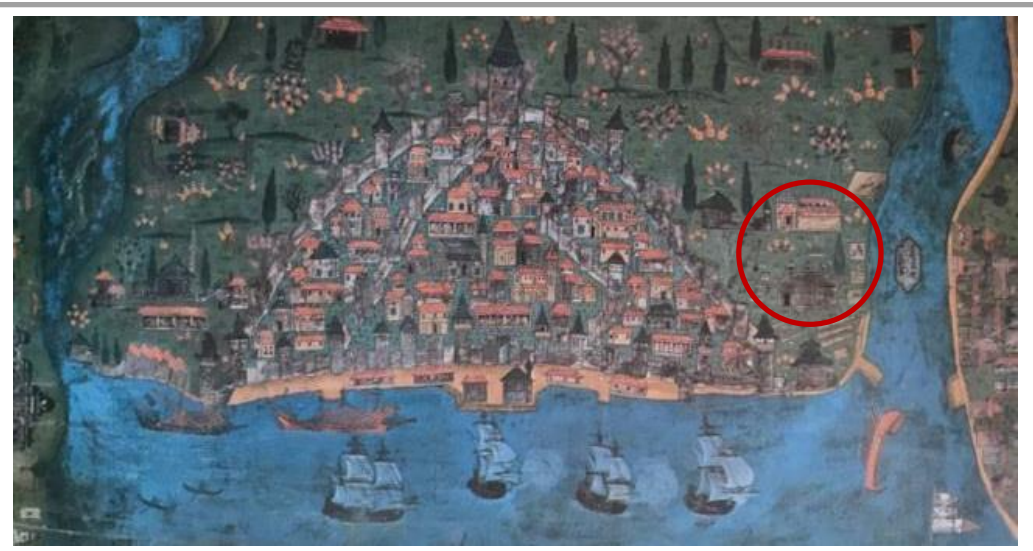

Şekil 1: Galata Sarayı ve Çevresini Gösteren Matrakçı Nasuh’un Galata Minyatürü (Matrakçı Nasuh, 1533).

I. Mahmut devrinde (1730-1754) komplekse bir kütüphane ilave edilmiştir ve bu kütüphane İstanbul'un en zengin kütüphanelerinden biri haline getirilmiştir. III. Selim ve II. Mahmut da mektebin eğitim faaliyetlerine önem göstermişlerdir, mektep 1831 senesine kadar devlet hizmetlerine adam yetiştirme görevine devam etmiştir. Bu tarihten sonra enderun mektebi olma niteliğini kaybedip 1838'de Mekteb-i Tıbbiye'nin kurulmasıyla süregelen eğitim sistemi tamamen değiştirilerek batılı bir eğitim anlayışı benimsenmiştir. Yapı, geçici olarak 1862-1863 yılları arasında askeri kışla olarak kullanılmış ve 1868 yılında Mekteb-i Sultani'nin kurulmasıyla lise seviyesinde bir eğitim programı uygulanmaya başlanmıştır. Kurum, cumhuriyetin ilan edilmesiyle birlikte eğitim faaliyetlerini Galatasaray Lisesi adı altında halen sürdürmektedir (Kılıçoğlu vd., 1971: 911-912).

\section{Beyoğlu ve Çevresindeki Önemli Yangınlar}

Beyoğlu 17. Yüzyılda Galata'nın hinterlandı olarak yapılaşmaya başlamıştır. Beyoğlu ve çevresindeki kent dokusunu en çok etkileyen yangınların da yine 17. yüzyılda çıkan Galata yangınları olduğunu söylemek mümkündür. Bu durumun nedeni o dönemin binalarında genellikle ana yapı malzemesi olarak ahşabın kullanılmasıdır. 17. yüzyılın kayda geçen en önemli yangını 1660 yılında Galata surunun Karaköy Kapısı önlerinde meydana gelen yangındır. Galata bölgesinin büyük bir bölümünün etkilendiği bu yangında ahşap yapıların dışında kilise yapıları gibi kâgir binalar da zarar görmüştür (Cezar, 1963: 337). 18. yüzyılın en önemli yangını ise 1771 yılında Galata'da çıkmıştır. Bunun dışında, Abdülkadir Rumi Tekkesi ve Galata Mevlevihanesinin yanmasına neden olan 1765 Tophane yangını ve 1767 Beyoğlu yangını da yüzyılın önemli yangınlarındandır (Cezar, 1963: 362$363)$.

Beyoğlu bölgesinde ortaya çıkan yangınlar en çok 19. yüzyılda yoğunlaşmıştır. Bu yüzyılın kayda geçen ilk yangınları 1804 Tophane ve 1807 Galata yangınlarıdır. Bunların ardından; 1811, $1817,1823,1831,1848$ ve 1870 yıllarında Beyoğlu'nu etkileyen yangınlar meydana gelmiştir ve bu yangınlardan en geniş çaplı olanları 1817 ve 1870 yangınlarıdır (Cezar, 1963: 366-376). 1817 yangını Tophane semtinden başlayıp şiddetli lodos rüzgarı nedeniyle Beyoğlu'na kadar ulaşmış ve ahşap binalardan oluşan bölgenin büyük tahribatına neden olmuştur (İsfendiyaroğlu, 1952: 312). Bu yangın sonucunda Galata Sarayı da büyük zarar görmüş ve yeniden inşa edilmek zorunda kalmıştır. 1848 yangını, Journal de Constantinople gazetesinin 14 Ekim 1848 sayısında çıkan habere göre Galata Sarayı'nın çok yakınlarında, günümüzde Eski Çiçekçi Sokak olarak bilinen Linardi Sokak'ta bir evde çıkmıştır. Kısa sürede yayılan yangın o dönemde Mekteb-i Tıbbiye olarak kullanılan Galata Sarayı binasının tamamen yanmasına neden olmuştur (Şekil A.1.c) (JCEO, 1848: 1). 1870 yangını ise büyük Beyoğlu yangını olarak tarihte yerini almıştır. Taksim dolaylarında başlayan bu yangın Galatasaray'a kadar neredeyse tüm Beyoğlu'nun yanmasına neden olmuştur. 7 Haziran tarihli La Liberté gazetesine göre bu yangın sonucunda yaklaşık on bin kadar yapının zarar gördüğü tespit edilmiştir. Bu yapılar arasında Naum Tiyatrosu gibi ünlü ve önemli yapılar da vardır; ancak Mekteb-i Sultani bu yangından 
etkilenmemiştir. Bu yangın Beyoğlu'ndaki ahşap binaların kâgirleşmesinin önünü açmıştır (Akın, 1998: 302-303).

Bahsi geçen yangınlar arasında Galatasaray'ın zarar görmesine neden olanlar; 1817, 1831, 1848 yangınları ve okulun içinde çıkan 1907 yangınıdır.

\section{Yangını Sonrası Galata Sarayı'nın Geçirdiği İmar Faaliyetleri}

II. Mahmut döneminde meydana gelen 1817 yangını öncesinde Galata Sarayı büyük bir arazi içinde dağınık, tek katlı ayrı ayrı yapılardan oluşmaktadır. Çoğu ahşap olan bu yapıların bir kısmı çift katlı ve yarım kâgirdir. Bunların iç bölmeleri, tavanları, zemin döşemeleri ve merdivenleri ahşap, ara bölmeleri bağdadidir (İsfendiyaroğlu, 1952: 312-313). Mühendis Franz Kauffer'in 1776 yılında çizdiği İstanbul planı incelendiğinde yapının ana kütlesinin L formunda olduğu ve bu kütlenin etrafında daha küçük pavyon benzeri yapılar bulunduğu tespit edilmiştir (Şekil 2). Ana kütlenin kuzeyinde bir bahçe duvarı görülmektedir. Bu duvar L formlu ana kütlenin açık uçlarından birini kapatarak bir iç bahçe oluşturmuştur, duvarın İstiklal Caddesi'ne (Grande Rue de Pera) bakan ucunda cami olduğu düşünülen kubbeli bir yapı tespit edilmiştir. Kompleksin bir cami yapısı barındırdığı bilgisine, Fethi İsfendiyaroğlu'nun araştırmaları sırasında bulduğu Başbakanlık Arşiv Dairesi, Saray kısmı No. 1802 künyeli bir keşif defterinden ulaşılmıştır. İsfendiyaroğlu bu keşif defterinde, Galata Sarayı içinde yanmış olan cami ve diğer bazı bölümlerin tamiri için Hassa Mimarbaşısı Mehmet Rasim Efendi'nin görevlendirildiğinin yazılmış olduğunu ifade etmektedir (İsfendiyaroğlu, 1952: 319).

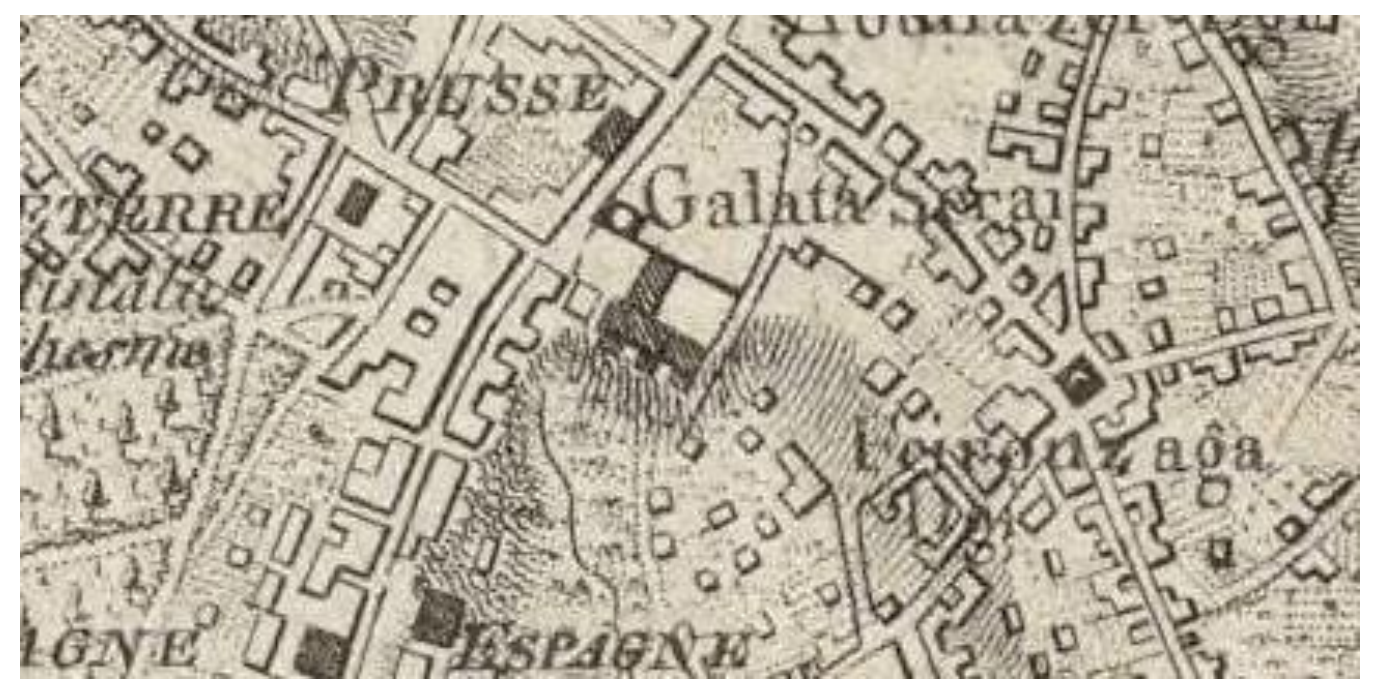

Şekil 2: 1776 Yılında Galata Sarayı ve Çevresi (Kauffer Haritası, 1776).

1817 yılında meydana gelip Galata Sarayı'nın büyük zarar görmesine neden olan yangın sonucunda yapının yeniden inşası 1820 yılında tamamlanmıştır. Yapı yeniden inşa faaliyetinde öncesindeki durumun bir bölümünü koruyarak değişikliklere uğramıştır. 1821 yılında Franz Karats ve Jean Denis Barbié du Bocage'ın 1786 - Franz Kauffer planını geliştirerek çizdiği planda Galata Sarayı'nın yeniden inşa edilmiş hali görülmektedir (Şekil 3). Bu planda eski L formundaki yapının; eski bahçe duvarının kuzeyinde cami kütlesine bitişik olarak bir yapı ve doğudaki sokak üzerine gelen ikinci bir yapı inşa edilerek tamamen kapalı formda, avlulu bir yapıya dönüştüğü gözlenmektedir. Cami yapısı aynı konum ve biçimini korumakla birlikte, yeni yapıya bitişik durumdadır. Bu anlamda binanın dağınık olan kütlesinin biraz daha kompakt bir kütleye dönüştüğü görülmektedir. Yeni yapının baş oda, orta oda, küçük oda, cami ve hünkâr köşkü bölümlerini barındırdı ğı, Ata Tarihi'nde yazılan manzum tarihçelerden ve bu bölümlere döşenmek üzere hasır satın alındığıyla ilgili arşiv belgelerinden bilinmektedir (İsfendiyaroğlu, 1952: 316-318). 


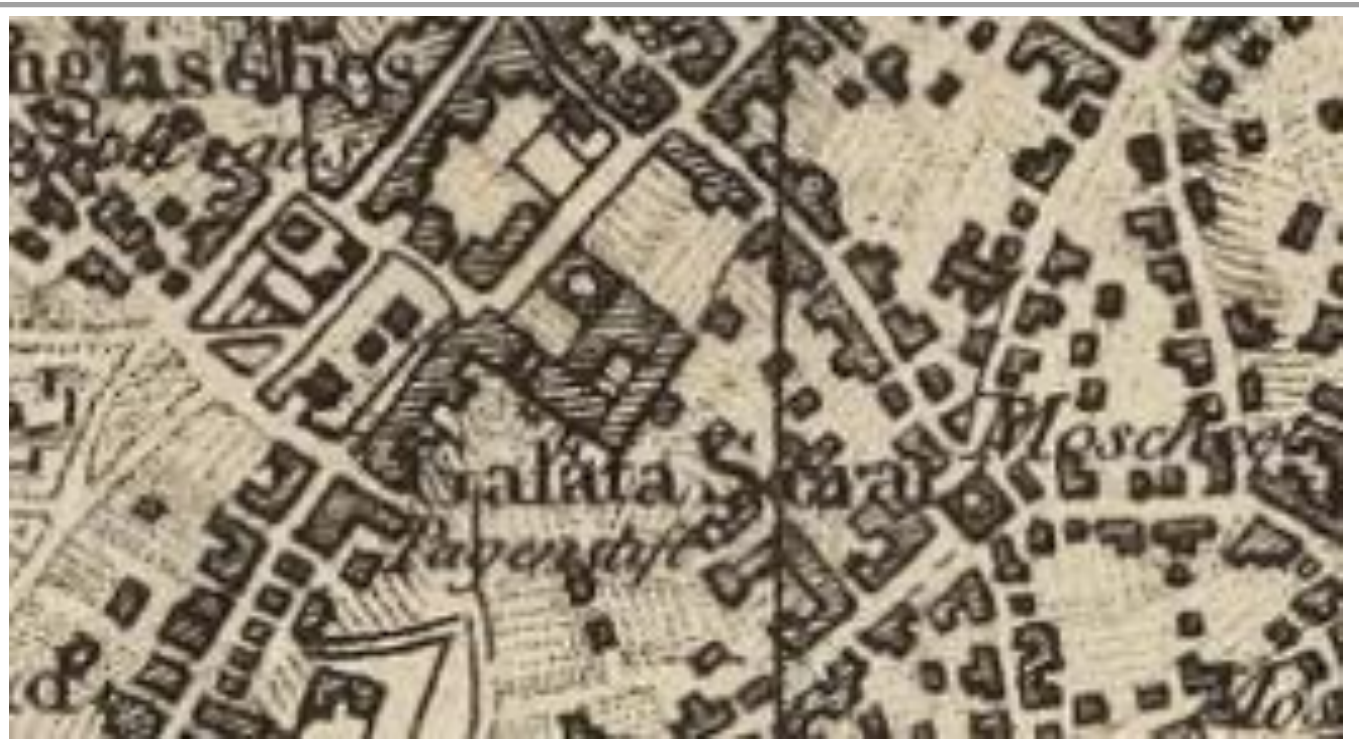

Şekil 3: 1821 Yılında Galata Sarayı ve Çevresi (Franz Karats - Jean Denis Barbié du Bocage Haritası, 1821).

Bunlarla ek olarak, o dönemde İstanbul'a gelen gezginlerin anı yazıları da bize birçok bilgi vermektedir. A. E. Castellan (1820: 73-74), Lettres sur la Morée, l'Hellespont et Constantinople adlı anı kitabında Galata Sarayı'ndan bahsetmektedir. Castellan, Galata Sarayı'nın karşısındaki binalardan birindeki bir dairede kalmaktadır. Kaldığı dairenin bir batılının ihtiyaç duyduğu eşya ve konfor düzeyi bakımından yetersiz olduğunu ancak penceresinden gördüğ̈ mükemmel manzaranın bu olumsuzluğa gölge düşürdüğünü söylemektedir. İç oğlanlarının, yani padişahın yanında hizmet edecek olan gençlerin mektebi olan Galata Sarayı binasının arazisini çevreleyen yüksekçe duvarın manzaradan zevk almasına engel olmadığını belirtmektedir. Castellan'a göre bina sol kısmından bakılınca heybetli bir kütle olarak görünmektedir. Haritalardan da gözlemlendiği üzere o yıllardaki Galata Sarayı binası, İstiklal caddesine daha yakın bir konumdadır. Bu nedenle yazarın da kendi dairesinden veya cadde üzerinden binayı rahatça görebildiği düşünülmektedir. Castellan yapının merak ve ilgi uyandıran birçok detay içerdiğini belirterek bazı gözlemlerini bize aktarmaya devam eder. Binanın ilk avlusunun S biçiminde eğri, uçları yere değen direklerle veya delikli dirseklerle desteklenmiş boyalı ve yaldızlı geniş bir çatı ile çok süslü bir kapısı olduğunu, bunlarla birlikte kırmızı ve maviye boyanmış tahta sütunlardan oluşan bir de galerisinin göze çarptığını söyler. Üst tarafları sivri, küçük, kafesli pencereler açılmış olan uzun duvarlar olduğunu ve bu duvarların üzerinde şerefeleri bir gotik sütun başlığını andıran, alemleri gümüş veya altından olan küçük beyaz minarelerin yükseldiğini belirtir. Castellan, binanın bitişiğindeki arazinin bir servilik olduğuna da değinir. Bu serviliğin gölgesi ve altındaki taze çimenin hem keçi sürüleri için bir çayır niteliğinde olduğunu, hem de iç oğlanlarının muhafizları ve zabitlerine bir gezi alanı olarak kullanıldığını ekler. O dönemlerde binanın dış cephesiyle ilgili bir veri olmadığı için bu anı yazısındaki anlatılar ve tasvirler bize yapı ve çevresi hakkında bilgi vermektedir. Dönem haritaları ve anılardaki tasvirler birlikte değerlendirildiğinde; yapının eski L plan şemasını korumakla birlikte yapılan eklemelerle değişime uğradığ 1 tespit edilmiştir.

\section{Yangını Sonrası Galata Sarayı'nın Geçirdiği İmar Faaliyetleri ve 1838 Yılında Mekteb-i Tıbbiye'nin Kuruluşu}

Galata Sarayı Enderun mektebi, 1820'deki yeniden inşasından kısa bir süre sonra 1831 yılında tekrar bir yangın geçirmiştir. Avrupa'dan İstanbul'a gelen seyyahların anı kitaplarında yangın sonucunda terkedilip harabeye dönmesi hakkında bilgilere ulaşılmaktadır. M. Michuad (1834: 111), Correspondance d'Orient adlı eserinde, padişaha hizmet edecek en yetenekli ve kabiliyetli gençlerin Galata Sarayı'nda yetiştirildiğini ancak kendi gördüğü dönemde bu mektebin harabe halinde 
olduğunu belirtir. Miss Pardoe (1838: 73) da, The Beauties of the Bosphorus adlı eserinde Galata Sarayı'nın yangın sonrası harabe oluşundan bahseder. İsmi top dökümhanesinden gelen Tophane semtinin sırtlarındaki tepede iç oğlanlarının eğitimine mahsus bir kurum olan Galata Sarayı mektebinin harabelerini gördügünü ve binanın Beyoğlu'nda çıkan büyük bir yangın sonucunda zarar görerek bu hale geldiğini belirtir. John Auldjo'ya (1835: 93) göre ise de, 1831 yangınında harabe haline gelen bu büyük kurum, zengin bir tüccar binanın arsasını ve enkazını satın almadıkça veya yabancı bir elçi burayı hibe olarak ele geçirmedikçe yeniden inşa edilemeyecektir. Yanan bina tekrar inşa edilerek 1838 yılında doktor yetiştiren, modern bir tıp okulu olan Mekteb-i Tıbbiye kurulmuştur (İsfendiyaroğlu, 1952: 337).

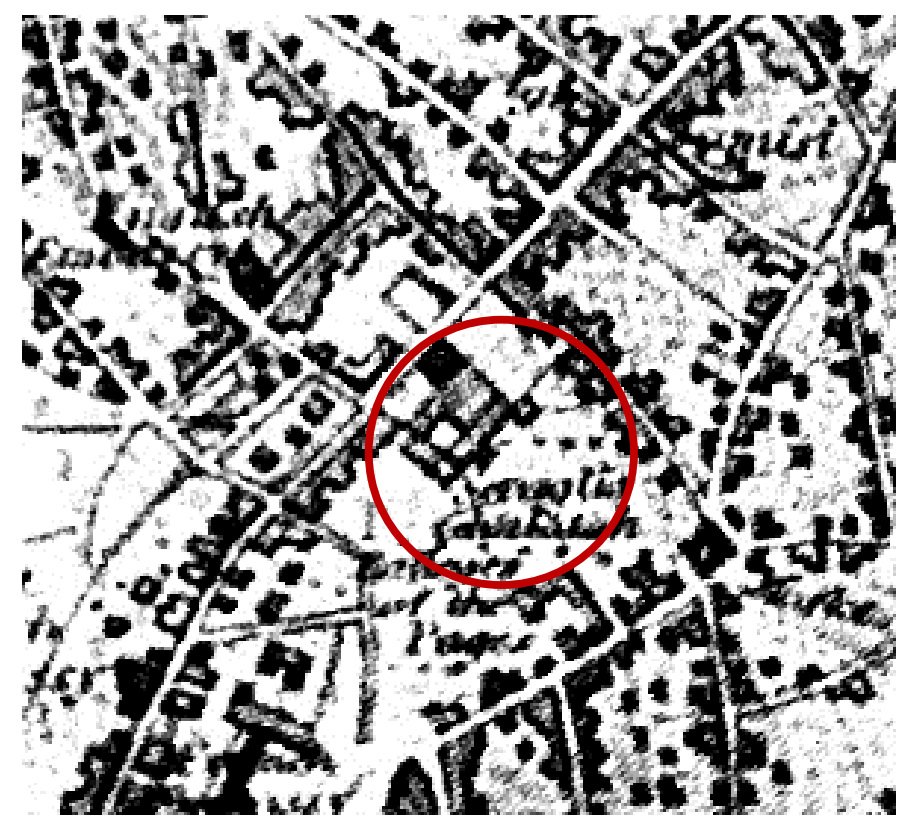

Şekil 4: 1840 yılında Mekteb-i Tıbbiye ve çevresi, Hellert Haritası (Kayra, 1990: 105).

Bu yap1 1840 tarihli Hellert planında görülmektedir. Yapı, önceki haliyle (Şekil 3) karşılaştırıldığında; kuzey kanadının iç avluya doğru genişlediği ve iç avlunun küçüldüğü görülmektedir (Şekil 4). Bunun dışında haritalar üzerinden bir değişiklik tespit edilememektedir. Yüksek duvarlarla çevrili komplekse, büyük kemerli bir kapıdan girilmektedir (Şekil 5). Buradan geçtikten sonra girilen büyük avlunun ortasında botanik bahçesi ve etrafında çok sayıda pencereleri olan binalar görülmektedir. Buranın ilerisinde yer alan ikinci avlu da binalarla çevrili olup, bir tarafında ince minareli bir cami, diğer tarafında padişah köşkü yer almaktadır. Devamında tıbbiye öğrencilerine ait yurt bölümü, derslikler, tatbikat salonları, anatomi salonu, yemekhaneler, yirmi odanın yer aldığı profesörler lojmanı ve hamam bulunmaktadır. Kompleks tamamen ahşap yapılardan oluşmaktadır (Şekil 6, 7). 1840 yılında 250 öğrenci bulunan tıbbiye 400 öğrenciye yetecek büyüklüktedir (Terzioğlu, 1992: 26-27). Mekteb-i Tibbiye'nin yeniliklerinden biri, bina içinde kurulan La Gazette Medicale de Constantinople'u basan matbaadır (litografya). Bunlar ana yaprya eklenen küçük binalardır. Aynı zamanda bu bölümde öğrenciler için ders notları da çoğaltılmaktadır (İsfendiyaroğlu, 1952: 352). Mektebin binasının yukarı avlusunun ortasında bir kütüphane ve bu kütüphaneye bağlı bir okuma odası bulunmaktadır (White, 1845: 190). Buradaki 'yukarı' avlu tanımı yapıda birkaç seviye avlu bulunduğunu ve bu anlamda da yapının mimarisinin topoğrafyayla bir ilişki kurmaya çalıştığını düşündürmektedir. Bunların dışında yapıya laboratuvar, dispanser ve aşıhaneler eklenmiştir (Ubicini, 1853: 205). Binada bir de ameliyathane bulunduğu bilgisine ise Başbakanlık Osmanlı Arşivi'nde bulunan, Mekteb-i Tıbbiye'nin ameliyathane harcamalarına dair bir belgeden ulaşılmıştır (BOA, C.SH. no:8,381). Ayrıca 14 Ekim 1848 tarihli Journal de 
Constantinople'daki habere göre yapıda, eczane, botanik bahçesi, seralar ve bir de müze bulunmaktadır (Şekil A.1.c) (JCEO, 1848: 1).

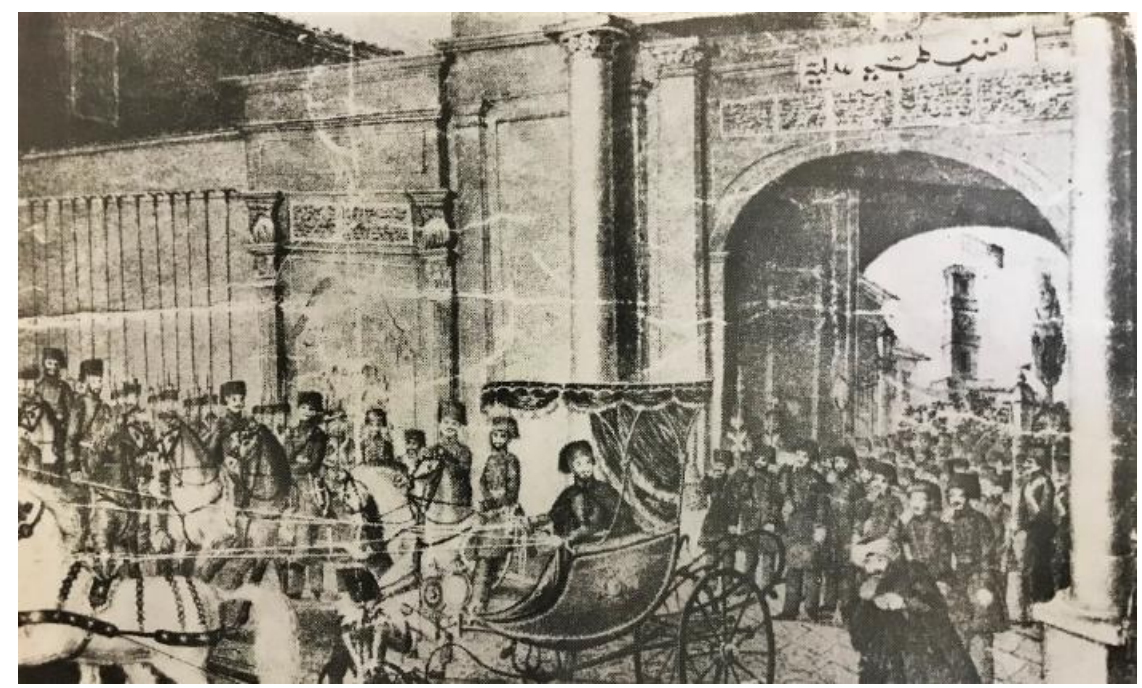

Şekil 5: 9 Eylül 1844'te Galatasaray'daki Mekteb-i Tibbiye-i Şahane'nin diploma töreninden Sultan Abdülmecit ayrılırken (Terzioğlu, 1992: 57).

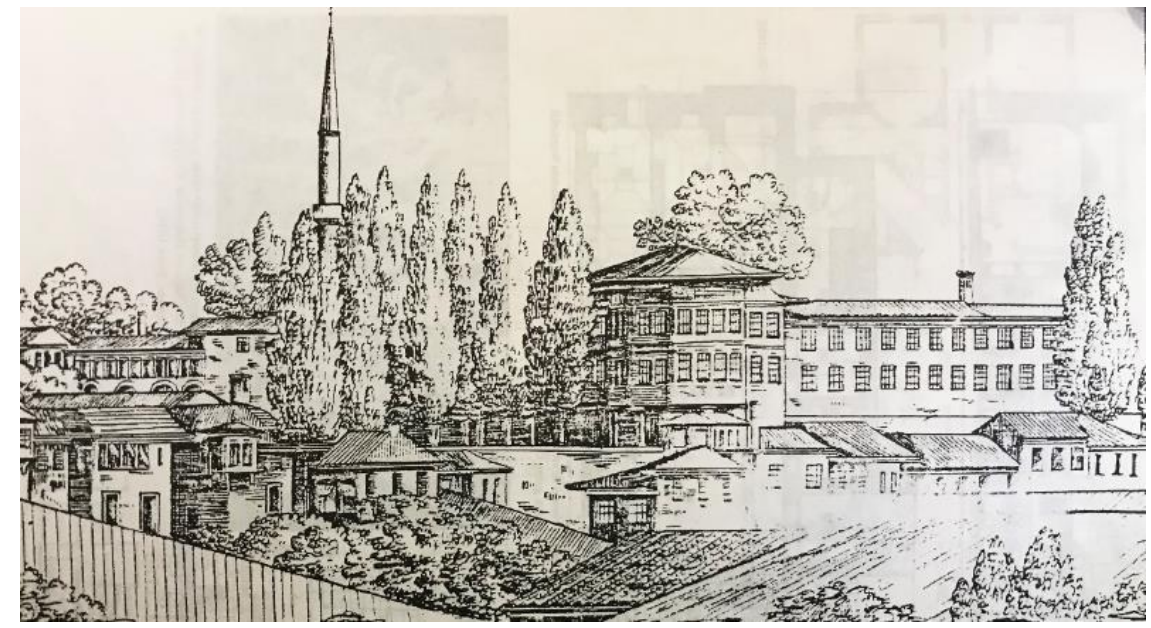

Şekil 6: Galatasaray'daki Mekteb-i Tıbbiye'nin 1839'daki durumunun J. M. Féraud tarafindan çizimi (Terzioğlu, 1992: 56). 


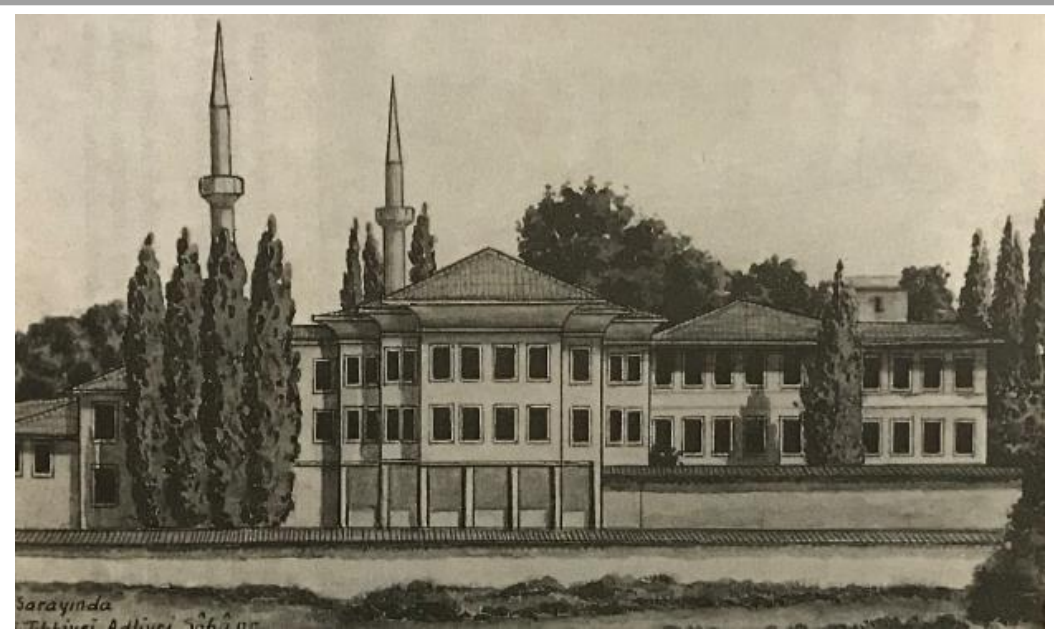

Şekil 7: Galatasaray’daki Mekteb-i Tıbbiye’nin İngiliz bir ressamın İstanbul panoraması üzerinden Prof. Dr. Süheyl Ünver tarafından çizimi (Terzioğlu ve Lucius, 1993: 45).

Yapının, Mekteb-i Tıbbiye için yeteri büyüklükte olmadığı ve 300 öğrenci, 10 amfi ve 150 yataklık bir hastane içeren Dolmabahçe sırtlarında yeni bir bina yapılması gerektiği ile ilgili haber 21 Ağustos 1846 tarihli Journal de Constantinople'da yer almaktadır (Şekil A.1.a) (JCEO, 1846: 12). Aynı haberin devamında Galatasaray'daki binanın ilk ve orta öğretime ayrılmasının düşünüldüğü belirtilmiştir. Aynı gazetenin 1848 yılındaki 14 Eylül tarihli başka bir haberinde tıp okulundan bahsedilmekte ve bu tıp okulunun Mösyö Smith tarafindan yapıldığı, Topçu Kışlası ve Askeri Kışla arasında bulunduğu belirtilerek detaylı mimari tasvirine yer verilmektetir. Galata Sarayı'nın o dönemde tıp okulu olarak kullanılması farklı kaynaklarda da görüldüğü üzere bu haberin Galata Sarayı binasıyla ilgili olduğu sorusunu akıllara getirmiş olsa da haberdeki veriler analiz edildiğinde burada bahsedilenin yeni tıp okulu yani günümüzdeki Taşkışla Binası olduğu anlaşılmaktadır (Şekil A.1.b) (JCEO, 1848: 1). 1848'de geçirdiği yangına kadar olan süre boyunca Galata Sarayı binas1, Mekteb-i Tıbbiye olarak varlığını sürdürmüştür.

\section{Yangını Sonrası Galata Sarayı'nın Geçirdiği İmar Faaliyetleri ve 1868 Mekteb-i Sultani'nin Kuruluşu}

1848 yılının Ağustos ayında çıkan büyük bir yangın binanın tamamen yanıp kül olmasına neden olmuştur (Ubicini, 1863: 205). Journal de Constantinople gazetesinin 19 Ekim 1848 sayısındaki bir habere göre yangın 11 Ekim günü meydana gelmiştir ve yapı kullanılamaz hale geldiğinden Mekteb-i Tibbiye, Haliç’teki humbarahane binasına nakledilmek zorunda kalmıştır (Şekil A.1.d) (JCEO, 1848: 2). İsfendiyaroğlu'nun aktardığına göre; Skarlatos Vizandios (186: c.2, s.70) bir anısında İstanbul'un en zengin kütüphanelerinden biri ve bununla birlikte matematik, tıp ve doğa bilimlerine ait pek çok gerecin de bu yangınla yok olduğunu belirtmiştir (İsfendiyaroğlu, 1952: 352). 24 Kasım 1848 tarihli Journal de Constantinople'ün bir haberinde aralarında Mösyö Smith'in de bulunduğu bir ekibin yanmış Galata Sarayı binasını keşfe gittiği ve harabeleri üzüntüyle seyrettikleri yazmaktadır. Pera yangınında zarar gören bu yapının rekonstrüksiyonu için, binanın planlarını daha önce çizmiş olan Mösyö Smith'in görevlendirildiği (Şekil A.1.e) (JCEO, 1848: 1) bilgisine ulaşılsa da bu bilgi başka bir kaynakla doğrulanamamıştır. Mösyö Smith'in Sultan Abdülmecit döneminde yapılan Mecidiye Kışlası, Gümüşsuyu Hastanesi, Tophane Köşkü gibi önemli yapıların mimari olan William James Smith olabileceği düşünülmektedir. 1857 yılında yayınlanan Journal de Constantinople'da Galata Sarayı'nın yerinde bir okul inşa edileceğinin hükümet tarafından ilan edildiğiyle ilgili bir haber yer almaktadır (Şekil A.1.f) (JCEO, 1857: 3). Yeni binanın tasarım ve inşa sürecinde rol alan mimar/mimarlar ile ilgili bir bilgiye ulaşılmamakla birlikte, Abdülmecid'in saltanatına denk gelen bu süreçte Galatasaray'a yapılacak olan yeni binada William James Smith'in görevlendirilmiş olabileceği düşüncesi bir soru işareti olarak kalmıştır. 
Galata Sarayı'nın yeniden inşasına Abdülmecid döneminde başlanmıştır ancak inşaatın uzun sürmesi nedeniyle yeni yapı 1862 senesinde Abdülaziz döneminde tamamlanabilmiştir. Bina, inşaatın bitimiyle bir yıl kışla olarak kullanılmıştır ve bunu takiben 1867 yılına kadar İdadi-i Umumi adı altında harbiye, bahriye, tıbbiye ve mühendishane öğrencileri için bir idadi mektebi olarak hizmet vermiştir (İsfendiyaroğlu, 1952: 378-379). 1868 yılında imparatorluğun ilk lisesi olan ve batılı eğitim anlayışını benimsemiş Mekteb-i Sultani, Galata Sarayı'nda açılmıştır. Levant Herald gazetesinin 3 Eylül 1868 'deki sayısında Lycée de Galata-Sérai olarak anılan Mekteb-i Sultani'nin açılmasının ardından 4 gün geçtiği ile ilgili bir habere yer verilmiştir (Şekil A.1.g) (LH, 1868: 2).

Yapı, önceki imar faaliyetleriyle karşılaştırıldığında en büyük değişimi 1848 yangını sonrasında geçirmiştir. İsfendiyaroğlu, Ata Tarihi'ni (c.1, s.186-187) kaynak göstererek, yeni yapının, ahşap yerine tamamen kâgir olarak sıfırdan inşa edildiğini ve üç kattan oluştuğunu ifade etmektedir. Binanın, önceki haline kıyasla temeli, duvarları ve bölmelerinin çok daha sağlam olduğu belirtilmektedir. (İsfendiyaroğlu, 1952: 378-379). 1873 tarihli, Sultan Abdülaziz döneminde yapılan bir kadastro haritasına göre bina, eski konumuna göre İstiklal Caddesi'nden (Rue de Pera) biraz daha iç kısma çekilmiştir ve İstiklal Caddesi'ne cephesi kalmamıştır. Cadde üzerinde sadece bahçe duvarı ve kapısı vardır. Önceki parçalı yapısının aksine bina, tek bir kütlede toplanmıştır. Yapının dikdörtgen avlulu formu korunarak giriş cephesine iki kanat eklenmiştir. Yangın öncesi haritalarda yapı kütlesinin kuzey batısına bitişik ve caddeye cephesi olan caminin bu haritada yer almadığı görülmüştür (Şekil 8).

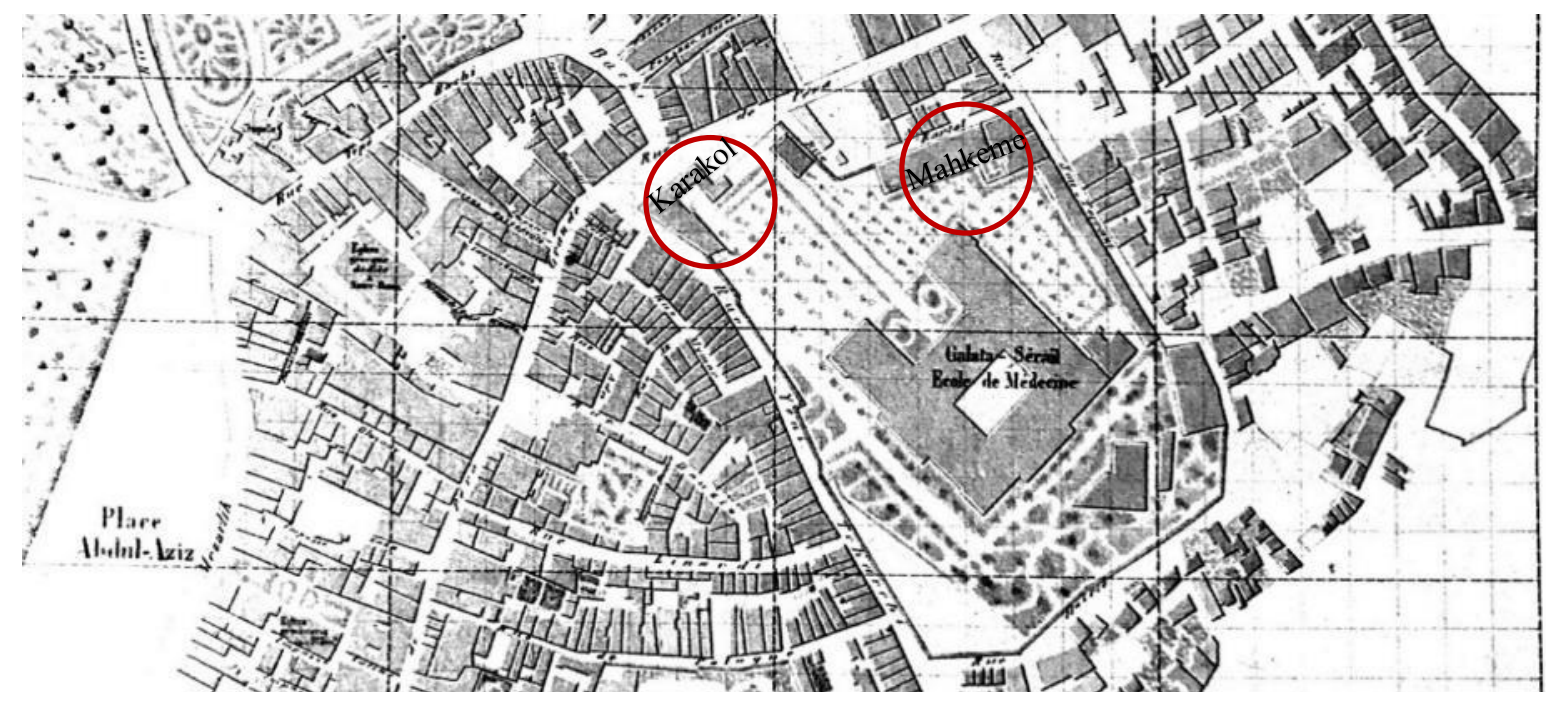

Şekil 8: 1873 yılında Mekteb-i Sultani ve çevresi, Sultan Abdülaziz zamanındaki kadastro çalışmalarından bir harita (Kayra, 1990: 68).

Dönemin haritaları incelendiğinde, Mekteb-i Sultani'nin İstaklal Caddesi'yle birleştiği köşede Galatasaray Karakolu bulunduğu tespit edilmiştir. Ayrıca Mekteb-i Sultani'nin kuzeydoğusunda, Kartal ve Su Terazisi Sokak kesişiminde, bugünkü Galatasaray İlköğretim Okulu binasının yerinde; "Chambre Correctionnelle du Tribunal de 1ere Instance" olarak geçen Beyoğlu Bidayet Mahkemesi Ceza Dairesi binası yer almaktadır (Şekil 8). Bu bilgiler 1887 tarihli Hüber haritasında (Şekil 9) ve 1905 tarihli Goad haritasında (Şekil 10) bulunmaktadır. Başbakanlık Osmanlı Arşivi'nde mahkeme binasının altına Mekteb-i Sultani jimnastik salonu bulunduğu ve binanın duvarlarına zarar verdiği gerekçesiyle başka yere taşınması talebi ile ilgili bir belge bulunmaktadır (BOA, MF.MKT. no:108,27). Hüber haritasında karakolun yanına bir hapishane yapısının eklendiği (Şekil 9) ve Goad haritasında da bu yapının genişletildiği görülmüsşür (Şekil 10). II. Abdülhamit koleksiyonunda bulunan Mekteb-i Sultani’ye ait planlarda tespit edildiği üzere yapıyla ilişkili veya bahçe içerisinde çeşitli yerlere dağılmış; kolonadlı, teneffüshane olarak kullanılan yarı açık mekânlar 
yer almaktadır (Engin, 2016: 153-154) (Şekil 11). Bu mekankarın inşaasıyla ilgili bilgiye Başbakanlık Osmanlı Arşivi'ndeki 1888 yılına ait Mekteb-i Sultani teneffüshanesinin inşa masraflarını içeren belgeden ulaşılmaktadır (BOA, İ. MMS. no:95,4042). Ayrıca Levant Herald'da, Mekteb-i Sultani'nin açılış yılında, halka açık dersler verildiği belirtilmekte ve bu derslerin içerikleri burada açıklanmaktadır. Gazetenin 19 Aralık sayısında konferansın yapıldığı salonun çok küçük olduğu, bu koca yapının halka açık derslere yetecek büyüklükte bir salon bulundurmadığı haberi yer almaktadır (Şekil A.1.h) (LH, 1868: 4). Başbakanlık Osmanlı Arşivi’nde, Pazar günleri halk için verilmekte olan derslere tahsis edilmek üzere Mekteb-i Sultani'nin yan tarafinda bir dersane yaptırılması ve inşaat masraflarının karşılanması ile ilgili 2 Mart 1869 tarihli bir belgeye de ulaşılmıştır (BOA, A.\} MKT.MHM. no:437,8). Fakat sonrasında bu dershanelerin yapıldığına dair yazılı kaynaklardan veya dönemin haritalarından bir veri elde edilememiştir.

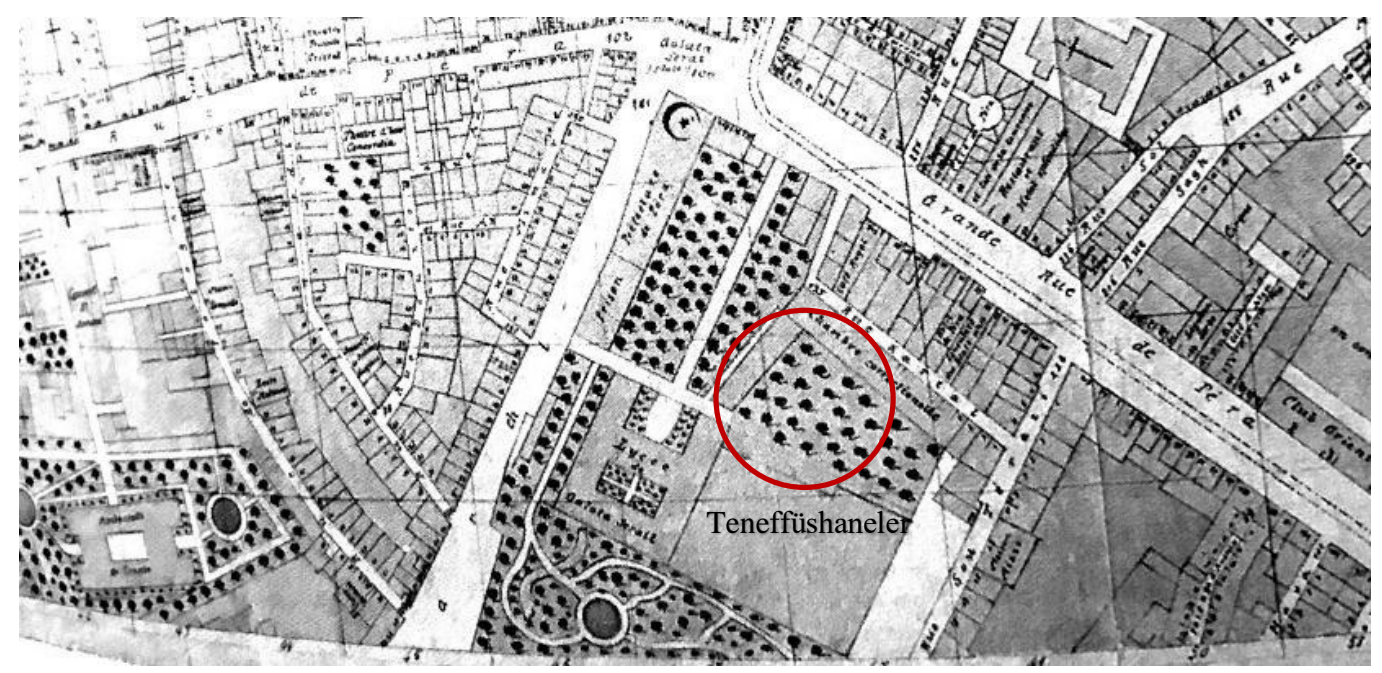

Şekil 9: 1887 yılında Mekteb-i Sultani ve çevresi, Hüber Haritası (Kayra, 1990: 69).

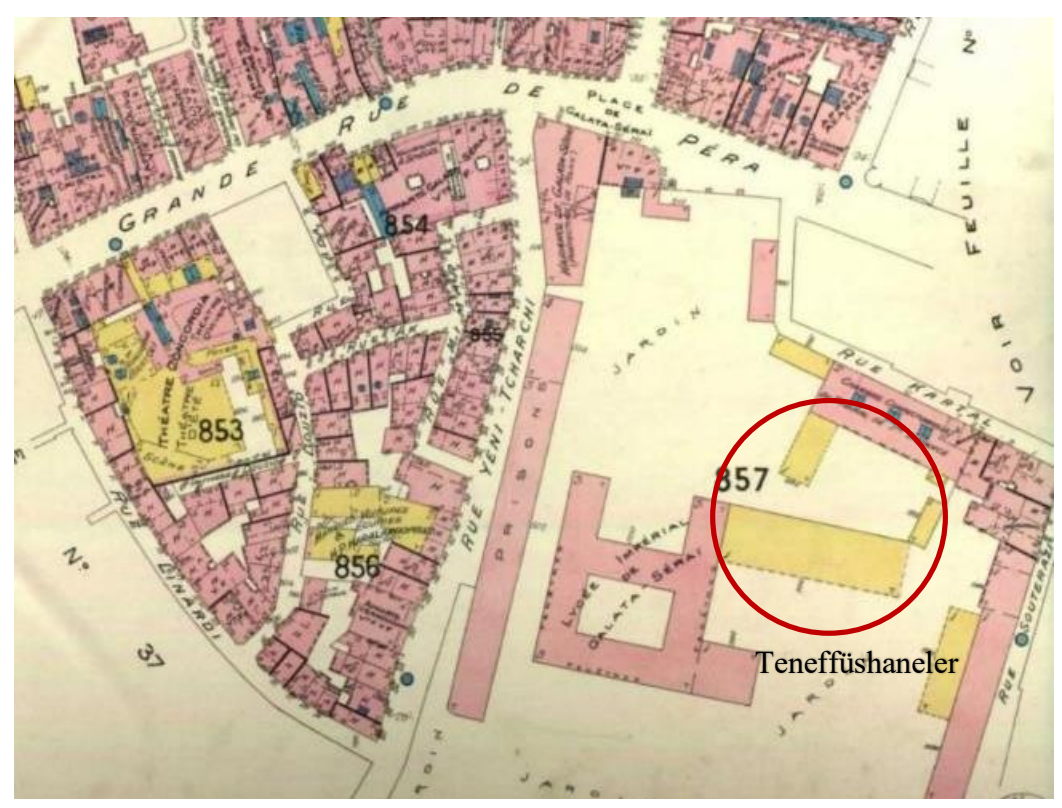

Şekil 10: 1905 yılında Mekteb-i Sultani ve çevresi (Goad Haritası, 1905).

1848 yangını sonrasında yapının geçirdiği en önemli değişim ana yapı malzemesinin kâgire dönüşmüş olmasıdır. Bu durumun hem dönemin Beyoğlu bölgesinde hem de Galatasaray özelinde ihtiyaçtan kaynaklandığını söylemek mümkündür. Journal de Constantinople'da yer alan haberde 
hükümetin, yapıların yangından zarar görmesinin önüne geçmek amacıyla tedbirler almaya karar verdiği ve bu tedbirler kapsamında her türlü masrafi göze alarak yapıların toğla ve taş gibi malzemelerle kârgir olarak yeniden yapılıcağı ile ilgili habere yer verilmiştir (Şekil A.1.c) (JCEO, 1848: 1). Yangınların bu kadar sık yaşandığı göz önünde bulundurulduğunda ahşap dönemin şartlarında sürdürülebilir bir malzeme değildir. Aynı zamanda yapı, enderun mektebi dönemindeki parçalı formundan tamamen kurtulup tek bir kütle haline gelmiştir.

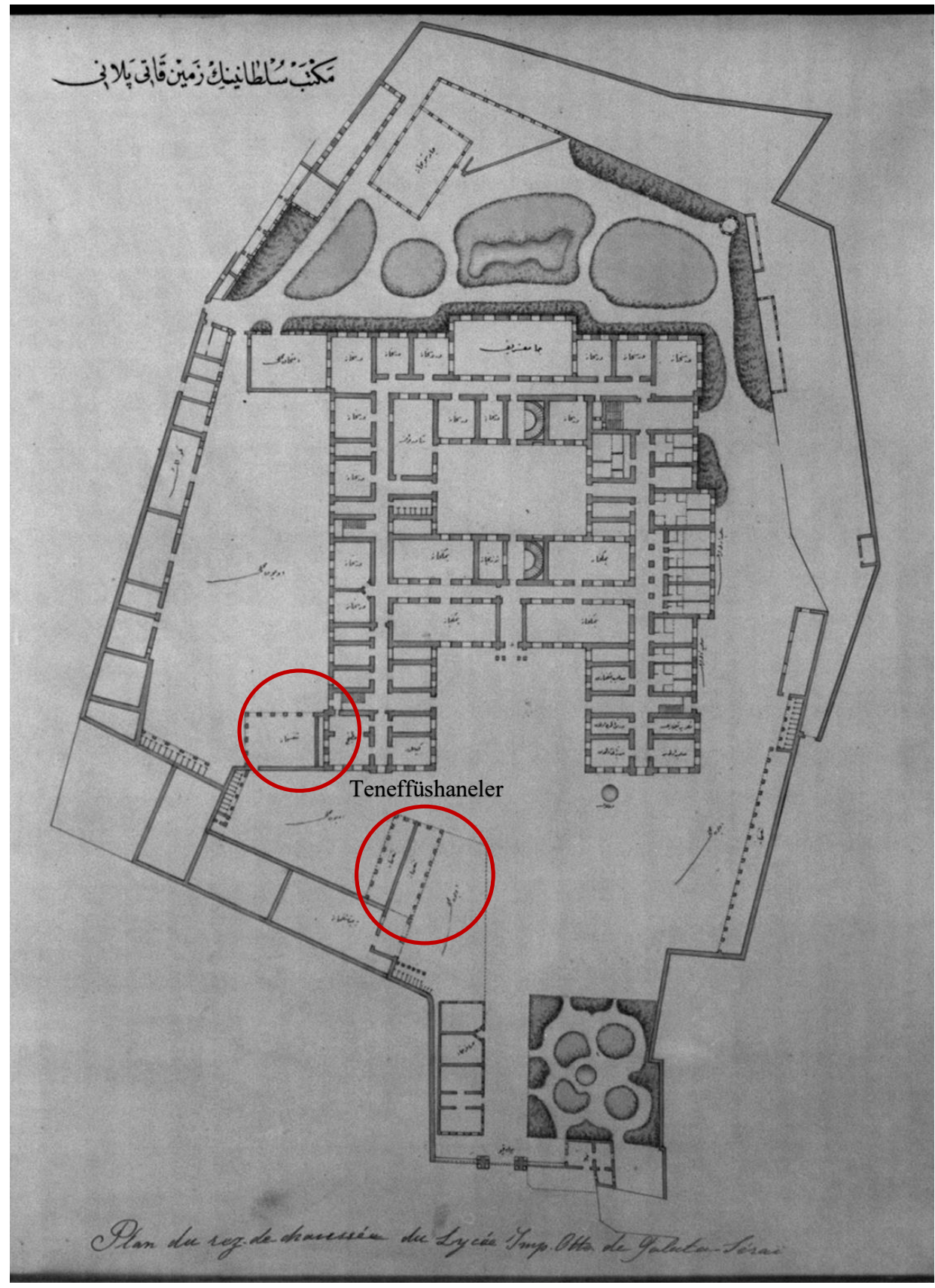

Şekil 11: Mekteb-i Sultani zemin kat ve çevresi planı (II. Abdülhamit Koleksiyonu, 1880-1900).

\section{Yangını Sonrası Galata Sarayı'nın Geçirdiği İmar Faaliyetleri}

1848 yılından 1907 yılına kadar olan süreçte 1870’te büyük Beyoğlu yangını çıkmıştır. Bu yangın Mekteb-i Sultani'nin İstiklal Caddesi sınırına kadar gelmişse de yapı, bu yangından zarar 
görmemiştir. Binayı etkileyen önemli yangınlardan en sonuncusu 1907 yılında olmuştur. Yangın, 7 Mart 1907 gecesi, okulun içindeki bir havagazı sobasının kaza ile alev alması sonucu çıkmıştır ve sadece okul binasını etkilemiştir. Duvarların kâgir olmasına rağmen iç bölmelerde, döşemelerde ve çatıda kullanılan ahşap, yangının etkisini artırmıştır. Bu yangında okul kütüphanesi, müzesi ve arşivi de yanmış olduğundan Mekteb-i Sultani tarihi açısından önem taşıyan birçok evrak yok olmuştur (Engin, 2016: 226-229). Bu yangınla ilgili, Başbakanlık Osmanlı Arşivi'nde Bab-1 Ali Evrak Odası fonunda bulunan 1 Mayıs 1907 tarihli bir belgede "Muhterik olan Mekteb-i Sultani binasının yeniden inşası için keşfinin icrası" ifadesi yer almaktadır (Şekil B.1) (BOA, BEO. no:3047,228451).

Yangın sonrası yapılan onarımlar yapının plan șemasını değiştirmemiştir. Sabah ve İkdam gazetelerinin 11 ve 13 Mart 1907 tarihli haberlerinden Mekteb-i Sultani binasının yangın öncesindeki iç mekan düzeni hakkında bilgiye ulaşılabilmektedir. Binanın sağ (batı), sol (doğu) ve ortada üç giriş kapısı vardır. Orta kapının iki yanında yemekhane; sağ tarafta gözetmen ve ders nazırı odaları, solda ise birinci ve ikinci sınıflar ile kütüphane birimleri yer almaktadır. Orta avlunun güneyinde kalan bölümde giriş aksında bir mescit, sağında sınıflar, müdür odası solunda sınıflar, kiler, mutfak ve şadırvan bulunmaktadır. İkinci kat, resmi birimler, 19 sınıf, müze ve kütüphane; üçüncü kat, ise on yatakhane, müdür daireleri (biri batı kanadında caddeye bakan, diğeri güneyde deniz tarafına bakan), bekçi odas1, depo ve revir birimlerinden oluşmaktadır (Engin, 2016: 225-226).

Yapının batısında yer alan hapishane binası 1905 yılında hazırlanan Goad haritasında görünürken (Şekil 10), 1927 yılında hazırlanan Pervititch haritasında bu yapıya rastlanmamaktadır (Şekil 12). Bu nedenle hapishane yapısının da bu yangında yanmış olabileceği düşünülmektedir. Hapishane yapısının yanında bulunan karakol yapısı yangından sonra hazırlanan 1934 tarihli Osman Nuri Ergin haritasında vardır, fakat yapı günümüze ulaşmamıştır (Şekil 13). Bu yapının ortadan kaldırılışı 1936 yılında Galatasaray Meydanı çevre düzenlemesi sırasında olmuştur. Akşam Gazetesi'nde bu binanın hükümet tarafından satılığa çıkarılıp bir bölümünün Galatasaray Lisesi bahçesine kalan kısmının da İstiklal Caddesi'ne verileceği ve satın alımdan sonra yapının yıktırılıp daha geriye yeni bir bina yaptırılabileceği ile ilgili bir haber bulunmaktadır (Akşam, 27 Mart 1936) (Şekil A.1.1).

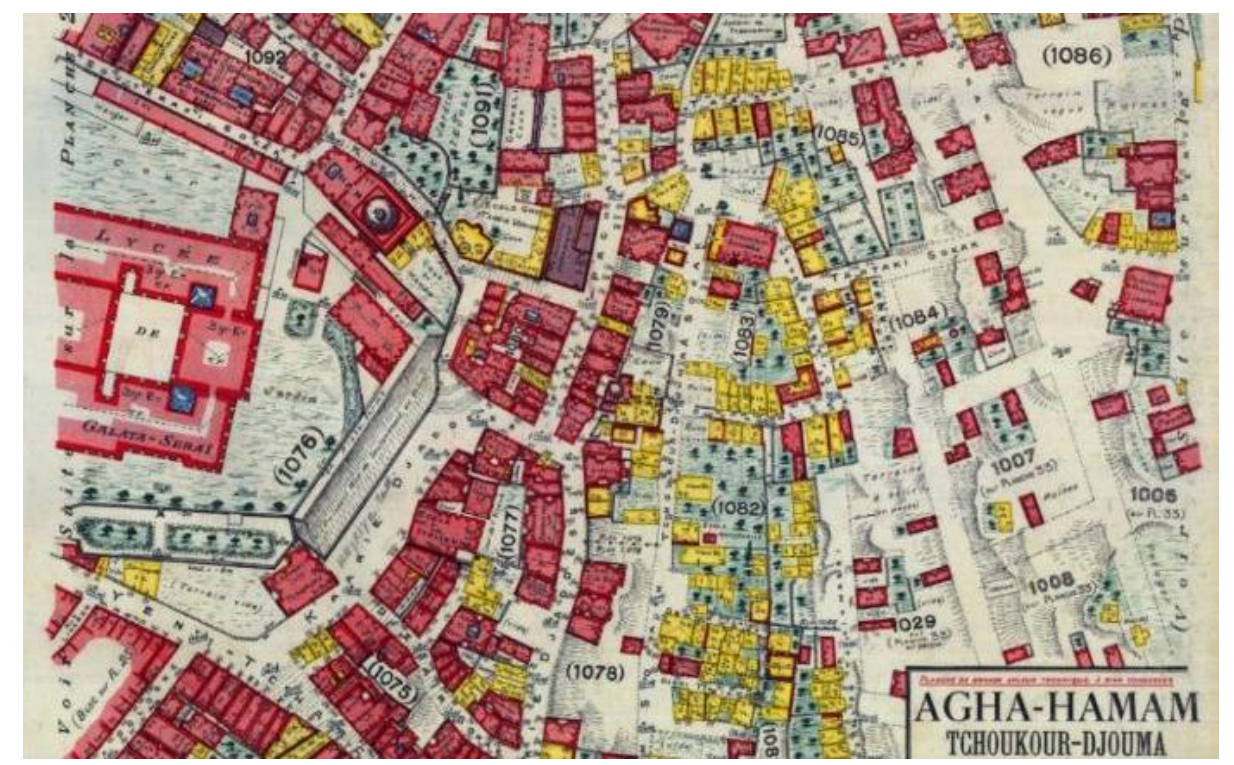

Şekil 12: 1927 yılında Mekteb-i Sultani’nin güney kısmı ve çevresi (Pervititch Haritası, 1927). 


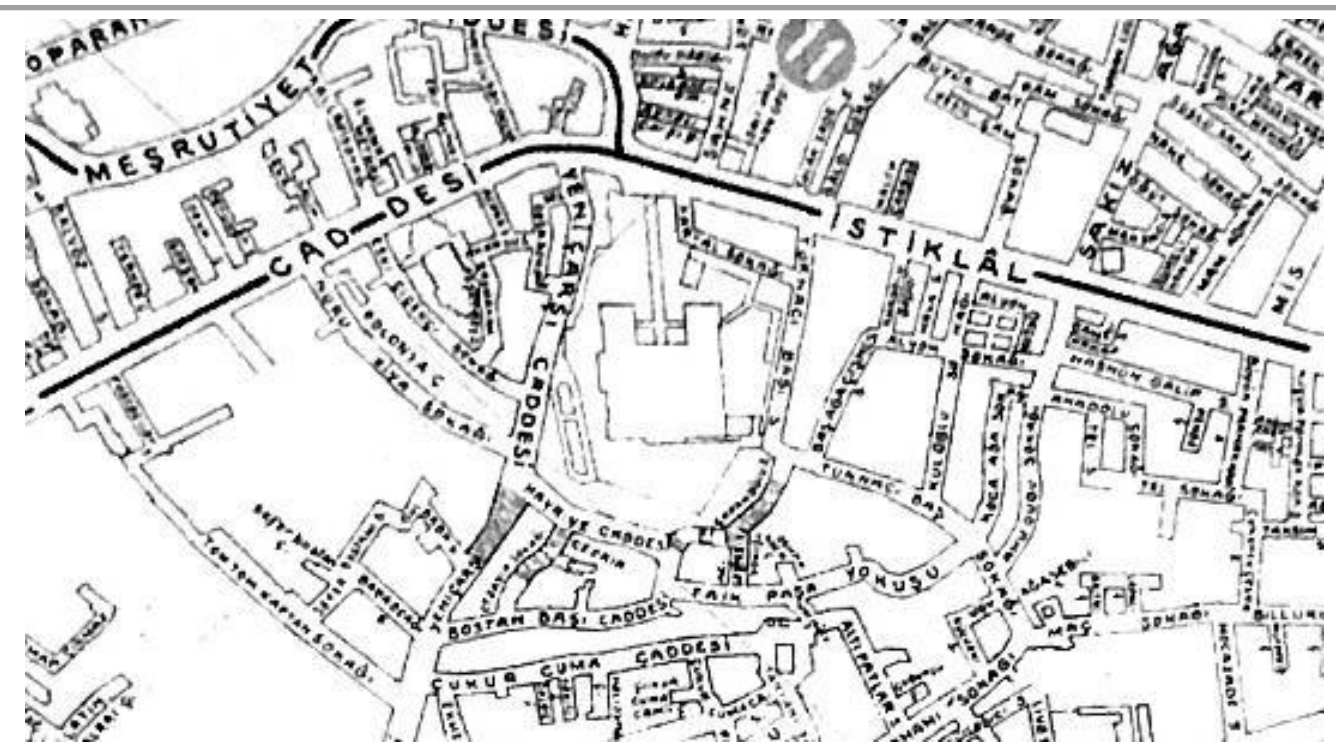

Şekil 13: 1934 yılında Mekteb-i Sultani ve çevresi (Osman Nuri Ergin Haritası, 1934).

Goad haritası (Şekil 10) ve Osman Nuri Ergin'in 1934'te hazırladığı Beyoğlu haritası (Şekil 13) karşılaştırıldığında yangın sonucunda binanın formunda bir değişiklik olmadı̆̆ 1 tespit edilmiştir. Goad haritası ve II. Abdülhamit koleksiyonunda yer alan 1880-1900 tarihli planlarda görülen teneffüshane olarak adlandırılan yarı açık mekânlardan mahkeme binasına bitişik olan, bu yangından sonra hazırlanan planlarda ve 1929 yılına ait fotoğrafta görülüyorsa da, doğu avlusu tarafindaki teneffüshane yapısının izine rastlanmamaktadır (Şekil 10, 11, 17; 13, 18). Yapının harap olmuş iç bölümleri, Tevfik Fikret'in müdürlügü döneminde sıfırdan inşa edilmiştir. Yapı bu değişimden sonra başka bir değişiklik geçirmemiş ve günümüze kadar bu haliyle ulaşmıştır. Fethi İsmail'in Galatasaray Dergisi'nde (Aralık 1931: 28) Söz Terbiyesi adlı makalesinde; dönemin müdürü Tevfik Fikret tarafından, yapının birinci katının güney kısmına bir konferans salonu (Şekil 14) ve bunun yanı sıra laboratuvarlar, fizik amfisi, kütüphane, eczane, revir gibi bölümlerin eklendiği bilgisi yer almaktadır (Engin, 2016: 244-245). Başbakanlık Osmanlı Arşivi'nde Mekteb-i Sultani içerisinde konferans ve diğer bazı durumlarda kullanılmak üzere ihtiyaç duyulan salon inşaatı için gerekenlerin yapılması ile ilgili bir belge tespit edilmiştir (BOA, MF.MKT. no:1112,46).

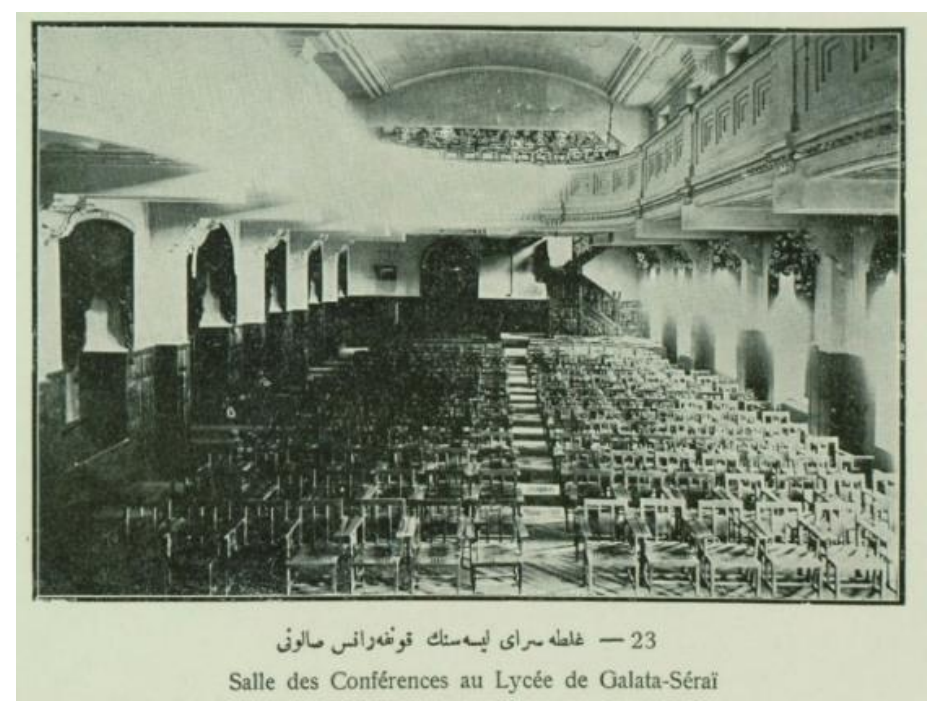

Şekil 14: Galatasaray Lisesi konferans salonu fotoğrafı (Maarif Albümü - La Vie Scolaire, 1928). 

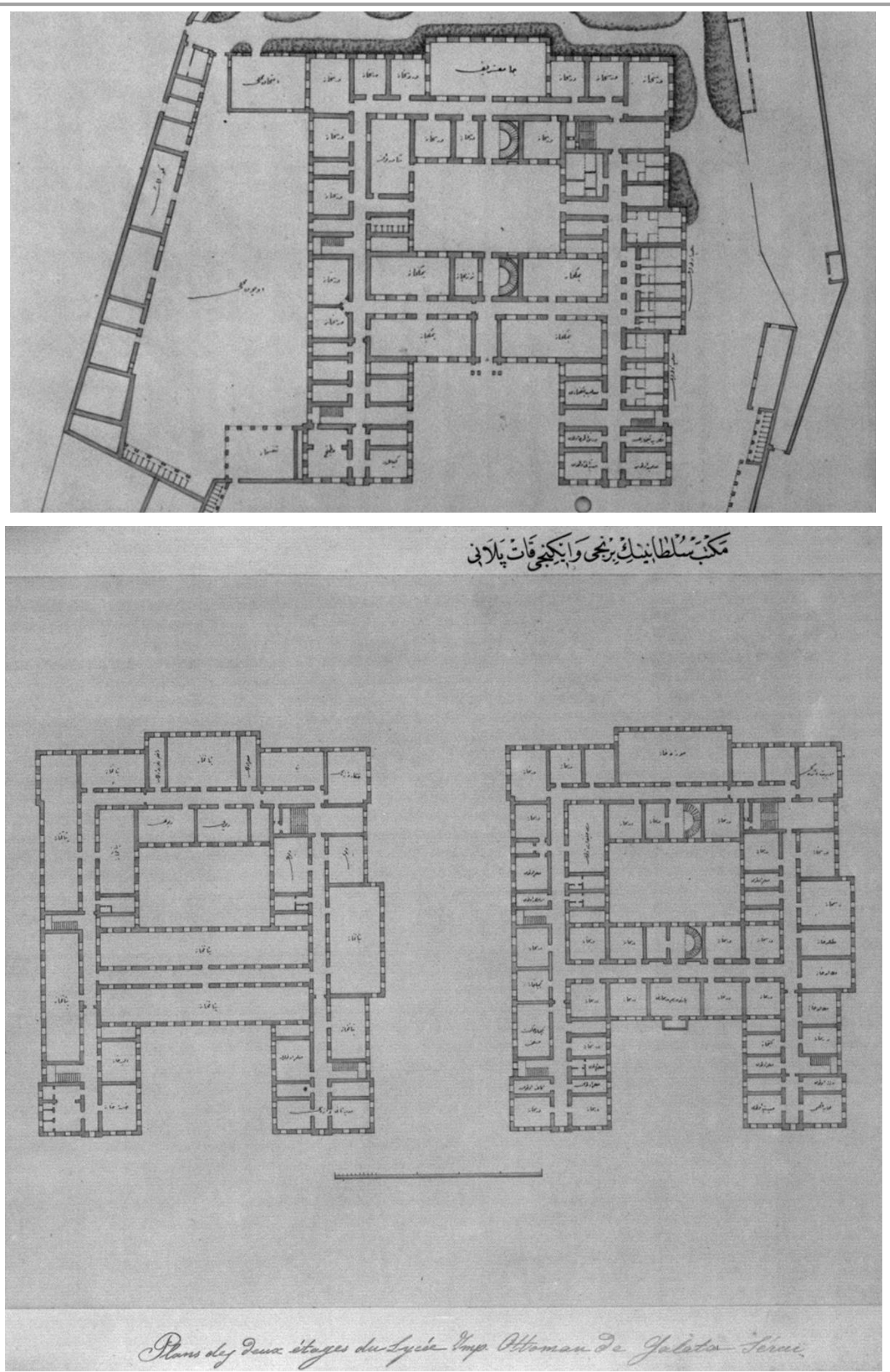

Şekil 15: Mekteb-i Sultani zemin, 1. ve 2. kat planları (II. Abdülhamit Koleksiyonu, 1880-1900). 
II. Abdülhamit Koleksiyonu'nda bulunan Mekteb-i Sultani'ye ait planlar ile yapının günümüzdeki hali karşılaştıııldığında giriş aksında bulunan dairesel merdivenin üç kollu merdivene çevrildiği görülmektedir (Şekil 15; 16). Bu merdivenin karşısında bulunan mekan da bu alana dahil edilerek birbirinin simetriği olan iki adet üç kollu merdivenle bir merdiven holü oluşturulmuştur. 1880 planında binanın güney kanadında yer alan iki merdivenden, ortada bulunan dairesel merdiven, yapının yeniden inşası sırasında yapılmamıştır. Bunun yerine bu kanatta avlunun batı köşesinde bulunan diğer merdivenin simetrisinde avlu doğu köşesine, Grand Cour (doğudaki bahçe) tarafina yeni bir merdiven eklenmiştir. Günümüzdeki öğretmen yemekhanesinin bulunduğu alanda (yapının batı cephesinin orta kısmında) yangın öncesinde kolonadlı hol oluşturan bir mekân görülmektedir. Yapının güneydoğusunda zemin katta çıkma yapan tek katıı mutfak mekânının üst katına günümüzde büyük amfi olarak kullanılan bir mekân eklenmiştir. Bunların dışında bazı bölme duvarların eski haline göre küçük değişikliklerle yeniden inşa edildiği görülmektedir. 1880-1900 ve 1929 yıllarındaki fotoğraflar karşılaştırıldığında, cephenin orta aksındaki saatin yer aldığı cephe elemanın farklı1ık gösterdiği saptanmıştır. Bunun dışında binanın cephesinde bir değişim tespit edilememiştir. Ek olarak 1929 tarihli fotoğrafta, bahçede peyzaj düzenlemesinin yapıldığı görülmektedir. (Şekil 17, 18). Yapının ana taşıyıcı malzemesinin kâgir oluşu yapının taşıyıcı duvarlarının yıkılmasını ve yangından etkilenmesini önlemiştir. $\mathrm{Bu}$ sayede yapının formunun ve cephe karakteristiğinin günümüze kadar korunduğu söylenebilir.
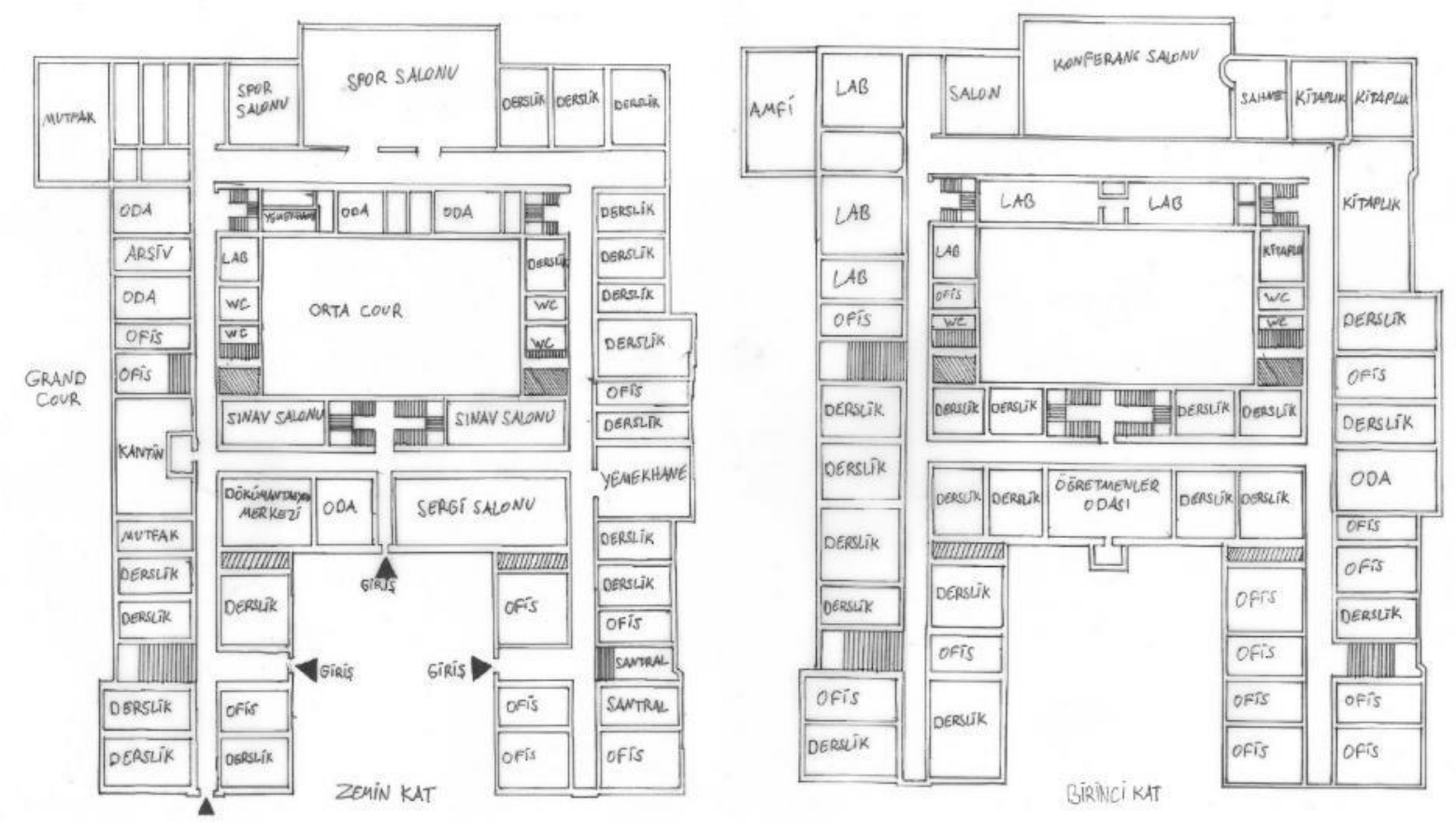

Şekil 16: Galatasaray Lisesi’nin güncel krokileri: Zemin kat krokisi ve birinci kat krokisi (Kolay, 2019). 


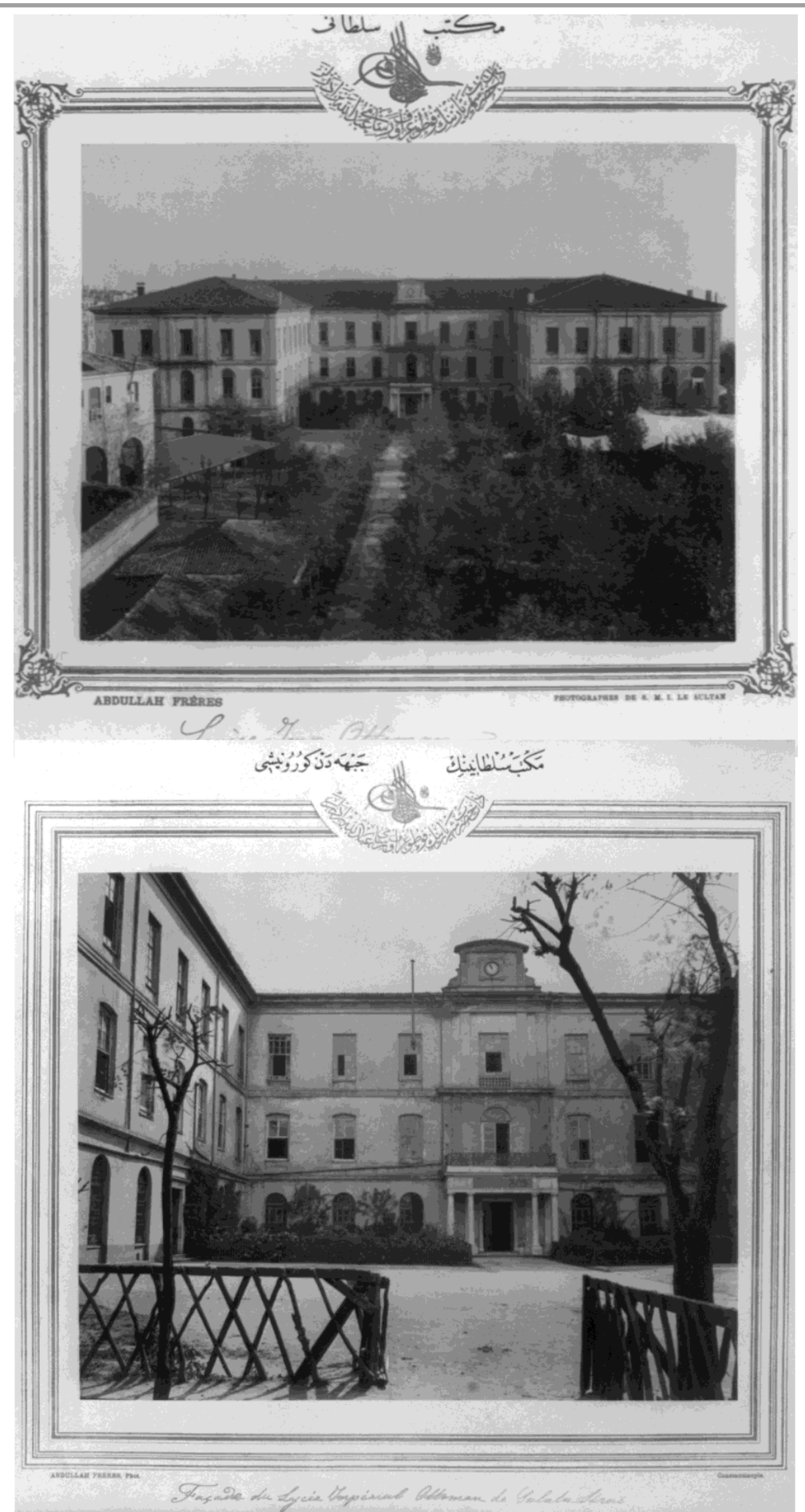

Şekil 17: 1880-1900 yıllarında Mekteb-i Sultani'nin İstiklal Caddesi yönünden fotoğrafları, (II. Abdülhamit Koleksiyonu, 1880-1900). 


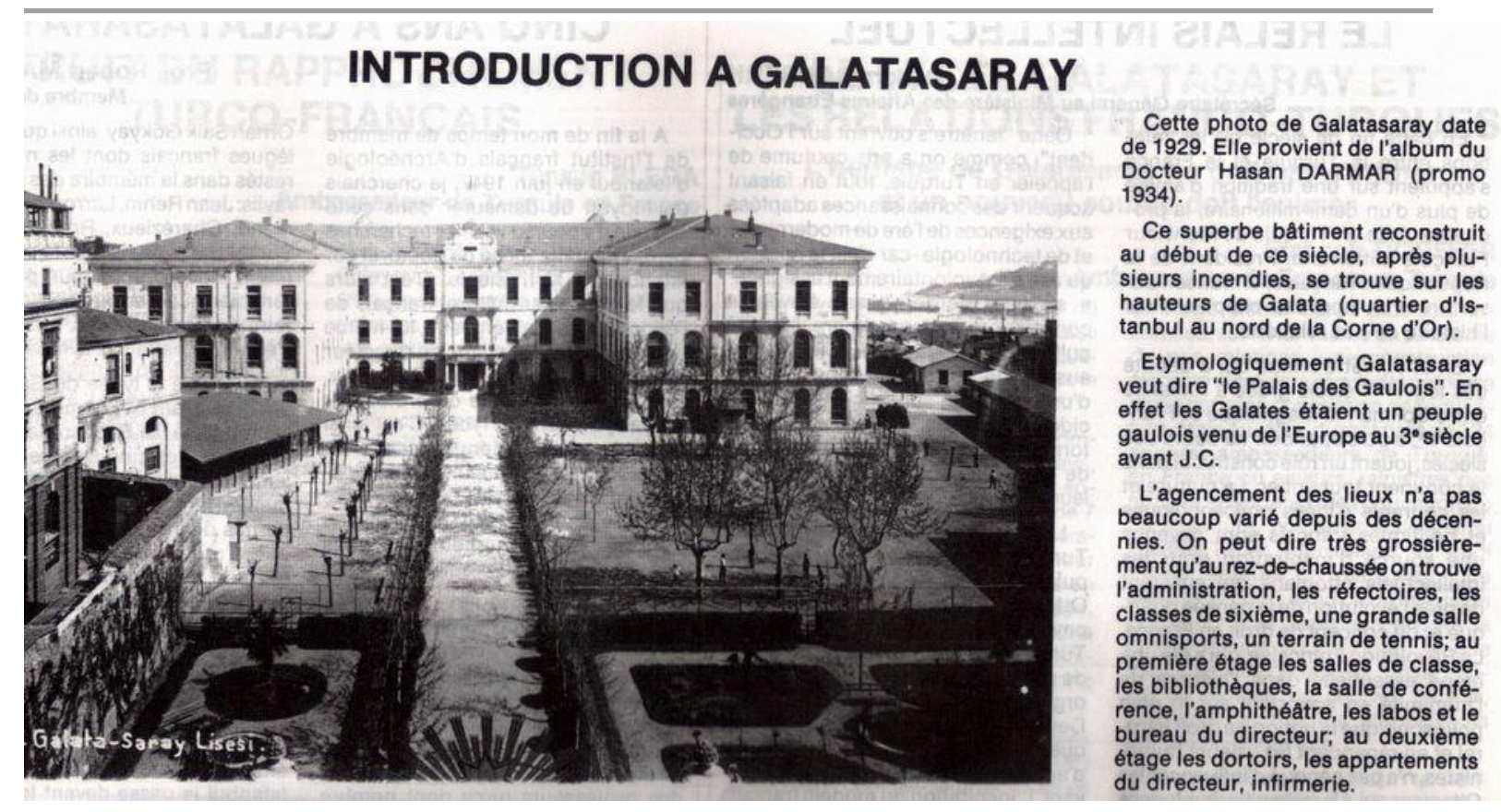

Şekil 18: 1929 yılında Mekteb-i Sultani'nin İstiklal Caddesi yönünden fotoğrafi (Darmar, 1929).

\section{Değerlendirme ve Sonuç}

Beş yüz yıldan uzun süredir varlığını sürdüren bir eğitim kurumu olan günümüzdeki ismiyle Galatasaray Lisesi, kuruluşundan günümüze pek çok defa yapısal ve fonksiyonel değişiklikler geçirmiştir. $\mathrm{Bu}$ araştırma kapsamında son yüzyıllarda yangınlar sonucunda mimari değişimlere neden olan imar faaliyetleri incelenmiştir ve bu değişimler saptanmıştır. Yapının tarihinde 19. yüzyıl ve 20. yüzyıl başlarında kayda geçen ve bu araştırmada ele alınan yangınlar 1817, 1831, 1848 ve 1907 yıllarında olmuştur.

19. yüzyılın ilk yarısındaki imar faaliyetleri ile ilgili, ulaşılabilen bilgiler daha küçük ölçekli haritalardan sağlandığı ve günümüze ulaşan bir iz olmadığ için çok detaya inilememiş, genel olarak bu küçük ölçekli İstanbul haritalarında görünen binanın kütlesi üzerinden yorum yapılabilmiştir. Yapının hangi bölümlerden oluştuğu bilgisine ve mimari tasvirlere dönemin yazılı kaynaklarından ulaşılabilmiştir. 19. yüzyılın ikinci yarısından cumhuriyetin kuruluşuna kadar olan süreçteki imar faaliyetleri daha detaylı bir ölçekte değerlendirilebilmiştir. $\mathrm{O}$ dönemde üretilen haritaların ölçeği daha büyüktür ve II. Abdülhamit koleksiyonunda bulunan 1880 yılına ait Mekteb-i Sultani kat planlarının çizimlerine ulaşılarak yapının günümüzdeki mevcut haliyle detaylı bir karşılaştırma yapılabilmiştir.

İmar faaliyetlerinin tümü incelendiğinde, yapıdaki en büyük değişimin, Mekteb-i T1bbiye döneminde meydana gelen 1848 yangını sonrasında, 1862 yılındaki yeniden inşa sürecinde olduğu tespit edilmiştir. $\mathrm{Bu}$ yangın, ahşap binanın tamamen yanıp kül olmasına neden olmuştur. Yeniden inşa edilen yapının, önceki imar durumundan farklı olarak konumunun değiştiği, caddeden daha içeri çekildiği gözlemlenmektedir. Yeni yapı, orta avlulu, girişte iki yandan dışarıya taşan kanatlı bir plan şemasına sahiptir. Üç katlı olarak inşa edilen binada kâgir yapım tekniği kullanılmıştır. Yapım tekniğindeki bu büyük değişim, Beyoğlu bölgesindeki kâgirleşme sürecine de denk düşmektedir.

Abdülmecit döneminde inşa faaliyetlerine başlanan binanın kullanım amacı kışla değilse de Abdülaziz döneminde tamamlanan yapı, bir yıldan kısa bir süre kışla olarak kullanılmıştır. Dönemin kışla yapıları olan Taşkışla, Gümüşsuyu Kışlası gibi yapılar incelendiğinde, simetrik plana ve iç avluya sahip oldukları görülmektedir ve yeni Galatasaray binasının da bu plan şemasına benzerlik 
gösterdiği tespit edilmiştir (Şekil 19). Bunun yanı sıra da Beyoğlu bölgesinde yer alan aynı dönemde yapılmış olan Venedik Sarayı ve Fransız Sarayı'nın plan şemaları ile de benzerlik göstermektedir. Galatasaray binasının planına bakıldığında, kuzey cephesinin iki yanında çıkma yapan iki kanadın ve iç avlusunun, bahsi geçen saray yapılarında da bulunduğu saptanmıştır (Şekil 19). Bütün bu örneklerde karşımıza çıkan plan tipolojileri ve Eklektik üslup, 19. yüzyılda Osmanlı'daki Batı etkisinin bir yansıması olarak nitelendirilebilir.
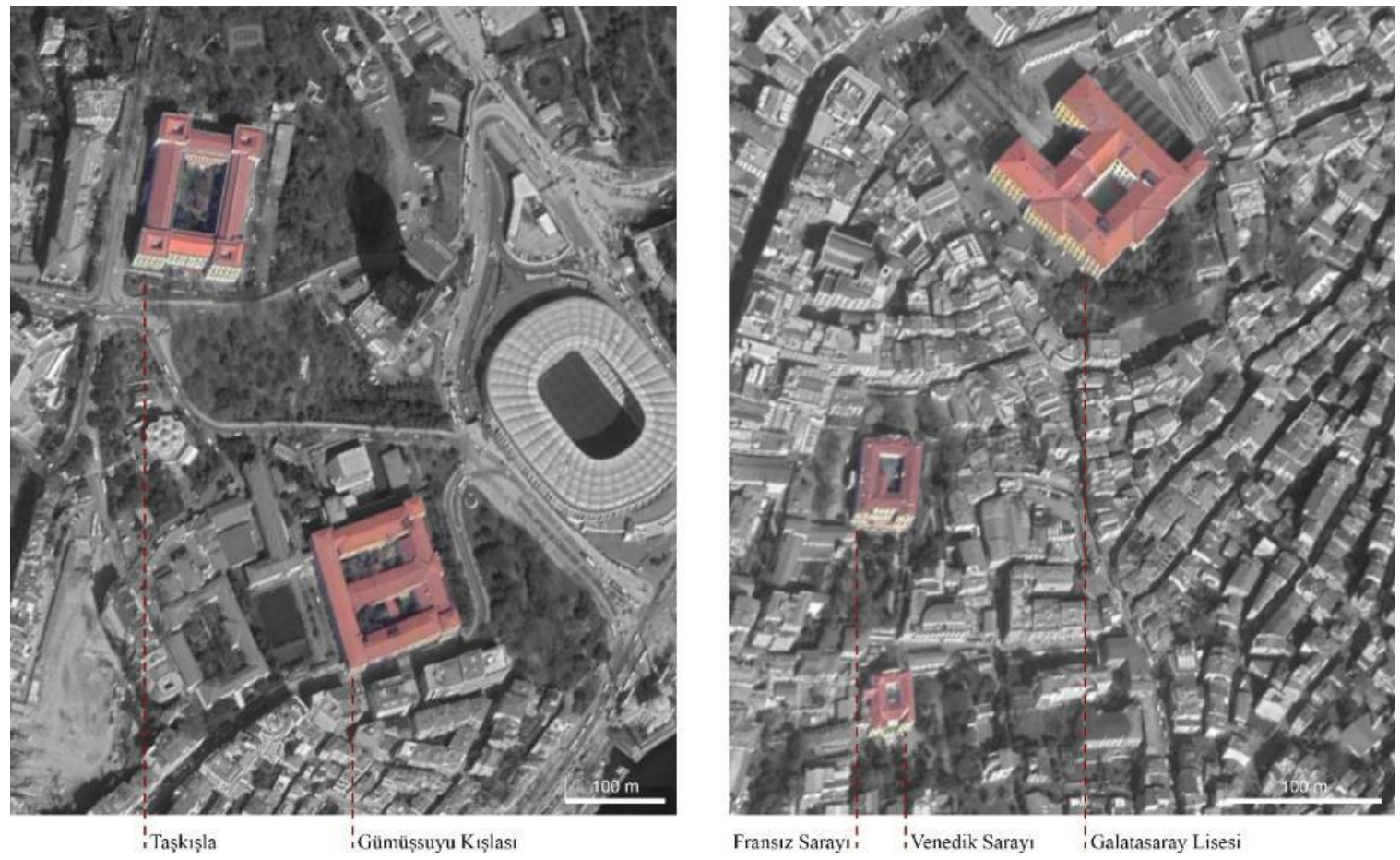

Şekil 19: Mecidiye Kışlası (Taşkışla), Gümüşsuyu Kışlası'nı ve Galatasaray Lisesi, Fransız Sarayı, Venedik

Sarayı'nı gösteren uydu fotoğrafları (Google Earth altyapısı kullanılarak hazırlanmıştır) (Balcı, 2019).

Sonuç olarak, mevcut belgeler çerçevesinde 15. yüzyıl sonundan günümüze kadar aynı yerde eğitim amacıyla kullanılan Galatasaray binasının değişim süreci incelenmiş ve en çok özgün belgenin bulunabildiği 19. ve 20. yüzyıl içinde geçirdiği yangınlar sonrasındaki imar faaliyetleri bu çalışmada ele alınmıştır. Araştırma sonucunda söz konusu yüzyıllarda, Galata Sarayı binasının yangın sonrası geçirdiği en büyük mimari değişikliğin, 1848 yangını sonrası yeniden inşasında ahşaptan kâgir yapım tekniğine geçerek öncesindeki küçük birimlerden oluşan parçalı formun, batı etkisinin gözlemlendiği tek kütleden oluşan bir forma dönüşümü olduğu görülmüştür.

\section{Kaynakça}

Abdül Hamid II Collection. (1880-1900). Mekteb-i Sultani, Washington, Library of Congress. https://www.loc.gov/search/?in=\&q=sultani\&new=true.

Akın, N. (1998). 19. Yüzyılın İkinci Yarısında Galata ve Pera. İstanbul: Literatür Yayıncılık.

Akşam. 1936-03-27. Milli Kütüphane Süreli Yayınlar.

Auldjo, J. (1835). Journal of a Visit to Constantinople: and Some of the Greek Islands in the Spring and Summer of 1833. London: Longman, Rees, Orme, Brown, Green \& Longman.

Başbakanlık Osmanlı Arşivi, C.SH. no:8,381. 
Başbakanlık Osmanlı Arşivi, MF.MKT. no:108,27.

Başbakanlık Osmanlı Arşivi, İ. MMS. no:95,4042.

Başbakanlık Osmanlı Arşivi, A.\}MKT.MHM. no:437,8.

Başbakanlık Osmanlı Arşivi, BEO. no:3047,228451.

Başbakanlık Osmanlı Arşivi, MF.MKT. no:1112,46.

Castellan, A. L. (1820). Lettres sur la Morée, l'Hellespont et Constantinople (2nd ed.). Paris: Chez A. Nepveu.

Cezar, M. (1963). Osmanlı Devrinde İstanbul Yapılarında Tahribat Yapan Yangınlar ve Tabii Afetler, Türk Sanatı Tarihi Araştırma ve İncelemeleri I (s.327-414). İstanbul.

Darmar, H. (1929). 1929 yılında Mekteb-i Sultani'nin İstiklal Caddesi yönünden fotoğrafi. http://gsl55.free.fr/images/logolar/ym_dokuman0012.jpg

Engin, V. (2016). Mekteb-i Sultani. İstanbul: Yeditepe Yayınları.

Franz Karats- Jean Denis Barbié du Bocage Haritas1 (1821). https://istanbulconstantinople.culturalspot.org/asset-viewer/plan-of-constantinopleistanbul/TQE_GOooKqwvdA.

Goad Haritası (1905). Osmanlı Bankası Arşivleri (OBA) Koleksiyonu.

İsfendiyaroğlu, F. (1952). Galatasaray Tarihi (c. 1). İstanbul: Doğan Kardeş Yayınları.

Journal de Constantinople Echo de L'Orient. 1846-08-21. (p.1-2). Bibliothèque National de France.

Journal de Constantinople Echo de L'Orient. 1848-09-14. (p.1). Salt Arşiv.

Journal de Constantinople Echo de L'Orient. 1848-10-14. (p.1). Salt Arşiv.

Journal de Constantinople Echo de L'Orient. 1848-10-19. (p.2). Salt Arşiv.

Journal de Constantinople Echo de L'Orient. 1848-11-24. (p.1). Salt Arşiv.

Journal de Constantinople Echo de L'Orient. 1857-04-06. (p.3). Salt Arşiv.

Kauffer Haritas1 (1776). https://istanbul-constantinople.culturalspot.org/assetviewer/i\%CC\%87stanbul-\%C5\%9Fehir-plan\%C4\%B1-ve-semtleri/hwF86T3hRkwFoQ.

Kayra, C. (1990). 1840 yılı Hellert Haritası, İstanbul Haritaları - Maps of Istanbul.Türkiye Sınai Kalkınma Bankası: 105.

Kayra, C. (1990). 1887 yılı Hüber Haritası, Eski İstanbul'un Eski Haritaları. İBB. Kültür İşleri Dairesi Başkanlığı Yayınları. No.1: 69.

Kayra, C. (1990). 1873 yıllı Sultan Abdülaziz zamanındaki kadastro çalışmalarından bir harita, Eski İstanbul'un Eski Haritaları. İBB. Kültür İşleri Dairesi Başkanlığı Yayınları. No.1: 68.

Kılıçoğlu, S., Devrim, H., \& Araz, N. (1971). Galata Saray1. Meydan Larousse (c. 4: 911-915). İstanbul: Meydan Yayınevi.

Levant Herald. 1868-09-03. (p.2). Salt Arşiv.

Levant Herald. 1868-12-19. (p.4). Salt Arşiv.

Matrakçı Nasuh (1533). Beyân-ı Menâzil-i Sefer-i 'Irâkeyn. Türk Tarih Kurumu Basımevi, Ankara (1976). S. 8a, 8b

Michaud, M. (1834). Correspondance d'Orient, 1830-1831 (Vol. 3: 111). Paris: Ducollet. 
Osman Nuri Ergin Haritas1 (1934). İstanbul Şehir Rehberi. Pafta no: 4/15

Pardoe, J. (1838). The Beauties of the Bosphorus. London: Pub. for the proprietors, by G. Virtue.

Pervititch Haritası (1927). APLPEAGHA32, Salt Arşivi.

Terzioğlu, A. (1992). İstanbul'da Mekteb-i T1bbiye-i Şahane, Türk İslam Hastaneleri ve Tababetinin Avrupa'da Tıbbi Rönesansı Etkilemesinden Türk Tıbbının Batılılaşmasına. İstanbul: Hipokrat Basım Yayım: 26-30.

Terzioğlu, A. ve Lucius, E. (1993). Mekteb-i Tibbiye-i Adliye-i Şahane ve Bizde Modern Tip Eğitiminin Gelişmesine Katkıları. İstanbul: Arkeoloji ve Sanat Yayınları.

Ubicini, A. (2016). Letters on Turkey (Vol. 1, s.205). La Vergne, Tennessee.

White, C. (1846). Three Years in Constantinople (2nd ed., Vol. 2). London: H. Colburn. 


\section{EKLER}

\section{EK A: Gazeteler}

\begin{tabular}{|c|c|}
\hline 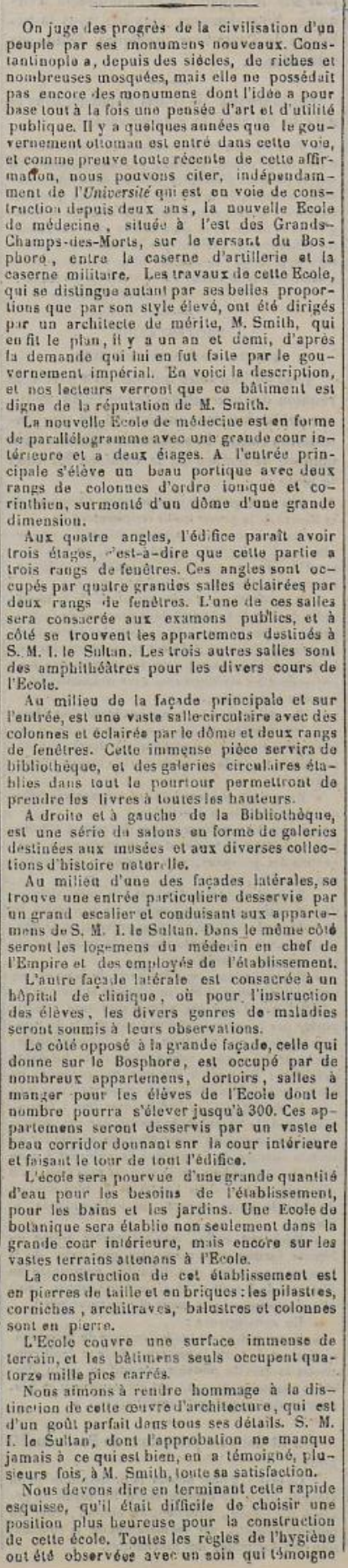 & 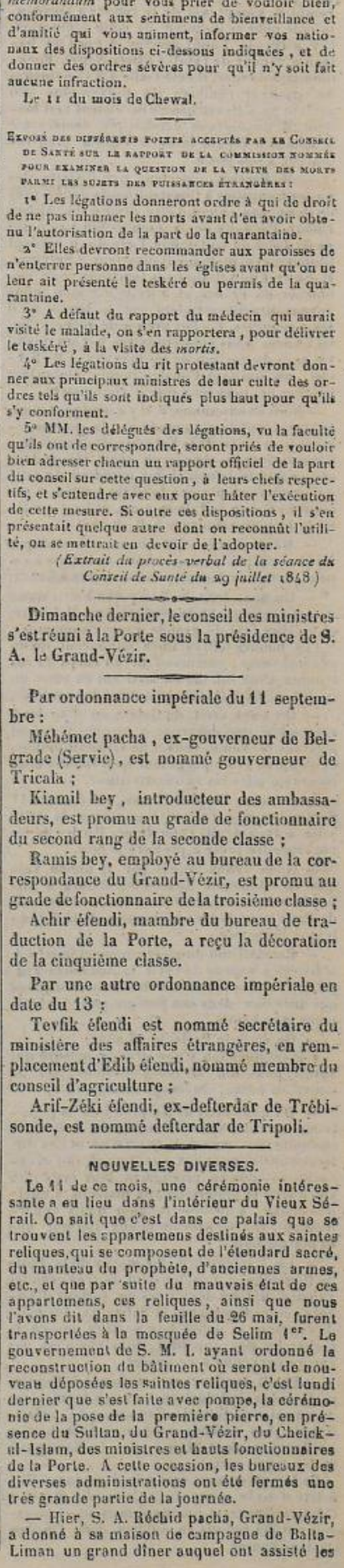 \\
\hline
\end{tabular}

\begin{tabular}{|c|c|}
\hline 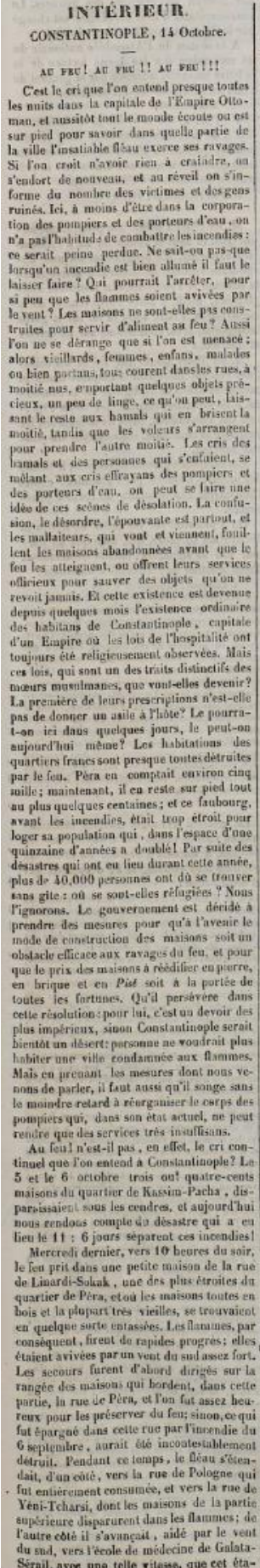 & 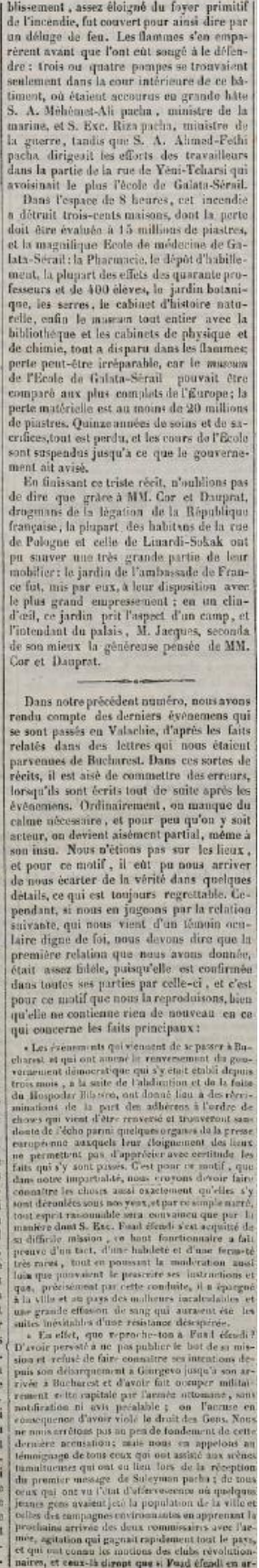 \\
\hline
\end{tabular}

(c) 


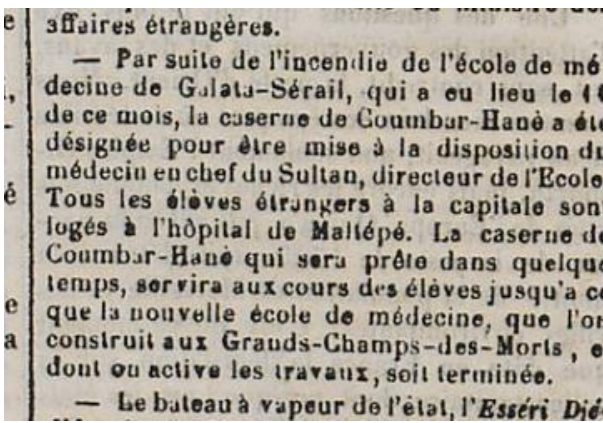

(d)

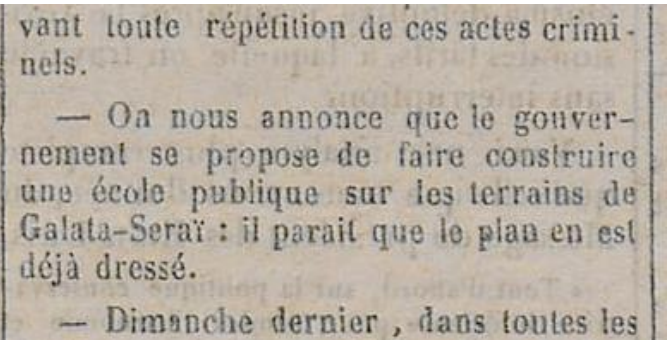

-Durant les quatre jours qui se sont écoulés depuis l'ouverture du Lycée de Galata-Séraï on y admis environ 150 élèves dont quarante Bulgares, Albanais et Grecs, venus du vilayel du Danube. Les cours ont déjì commencé, quant à la direction de l'établissement dont nous parlons, au lieu d'avoir été donnée à un musulman, comme il en avait été d'abord question, elle a été confiće à un Français, M. de Salve. Le sousdirecteur est, comme on sait, M. Lewisthal. On dit que la Porte a déposé $500,000 \mathrm{frs}$. pour assurer les traitements des professeurs, durant un certain terme, passé lequel, l'école devra voler de ses propres ailes. On parle avec éloge des nouveaux emmenagements intérieurs et de l'apparance du local de Galata-Sérai qui ne laisserait rien à désirer au point de vue de la propreté et même de l'élégance.

Galatasaraydaki karakol binan buikamet tarafindan satiligka çikarimi vo takdiri ksymet komisyonu tarafundan binays doksan bin litalik kiymet konmup. ta. 90 bin lira ile burassn almağga kimso talip olmamigur.

Aldığrmız mal0mata göre konan doksan bin liralik bu fiat, binanin satilacak kumuna aid dežlldir, heyeti umumiyesinedir. Halbuki binantn bir ktsmi, Gala. tasaray lisesinis bahçesine ilavo edilecek. ön kumi da caddeyo gỉdecektir. Bina Galatasaray lisesinin intikametine getirilecektir. Binanın bu suretlo küçülmes üzerise kalan parge satrlacaktsr ki bu kusmin de ell bin lira kadar tutacašl tahmin ediliyor.

Bina milli bankalardas biri tarafindan satin altnarak yikildiktan sonra bir az daha geriyo olmak tizere yeni bit bina yapilacaktur.
- Mardi dernier, S. A. Ahmet-Réthi pacha a douué, datus un des salons de TopHanì, un déjuAner, auquel étaient invitas LL. A A. Béchid pacha, gravd rézir, Mébémel. Ali pacha, minisıre de la fmorine; LL. BExc. Riza pacha,ministre de la guerre,Rifa'al pacha, président du conseil suprène de justic $\theta$; Mobmel pucba, ministre de la police; T. hir pacha, ministre de l'hótel des monnaies; is mail pacha, directeur des Iravans publics, le médecin en cbef de l'Empire, Abdulah éfen ii, et M. Smith, archilecte du palais d'Angleterre. A pres le déjetuner, les convives sont montés à cheval et se sont rondus a Galata-Sérail. Ils ont parcouru avec attention le vaste ol beau terrain de quarante-cinq mille pics de surface dont le plan avait été dressé d'avance par M. Smilb. Il s'agissait de déterminer la reconstruction du précious monument détruit dans le dernier incendie de Péra. A pres cel examen, le Grand-Vézir a dooné, de la part de S. Majesté, à M. Smith, l'ordre d'élablir les plans ol devis du nouveau batiment, dont los travaus seront mis sous sa direction.

Avant de quilter le quartier de Péra, les illustres visiteurs so sont rendus au nouveau theAtre qu'ils ont examiné en dótail, ot en se retirabı, ils ont adressé à l'archilecto l'expression do toule laur salisfaction.

CONAERRINCE DALATA SERAIL

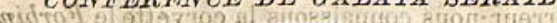

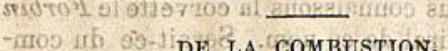

Ta salle ou foe font les conferencess be trourait beuncoup trop petite Dinanche dernier, pouricontenir la foule qui étaito accourue pour assister à la séance de M. Levisthal, sous-directeur du Lycée Impérial Ottoman. A une heure précise, la salle était comble et des personnes veiuues quelques instants plus tard, ne purent 1) y pénétrer. A cette occasion, qu'il nous soit permis d'émettre une opinion devant les faits qui se sont pas. sé́. Cet immense bâtiment du Lycée de Galata Sérail ne possède- $t$-il point une salle plus grande que celle où se font ordinairement les cours publics? Nécessairement, il est aisé de comprendre que pour arriver au bút auquel tendent les conférences que l'on y fait toutes les semaines, plus le nombre d'assistants est considérable et plus les effets sont grands. Ainsi donc par l'expérience de la séunce de Dimanche, nous avons pu juger qu'un local double a celui mis a la disposition du public à cet effet, ne serait pas trop grand par la foule quits'y porte. ess tor

Şekil A.1: (a) 1846-08-21, (b) 1848-09-14, (c) 1848-10-14, (d) 1848-10-19, (e) 1848-11-24 ve (f) 1857-0406 tarihli Journal de Constantinople; (g) 1868-09-03, (h) 1868-12-19 tarihli Levant Herald ve (I) 1936-03-27 tarihli Akşam Gazetesi haberleri 
Ek B: Başbakanlık Osmanlı Arşivi belgesi
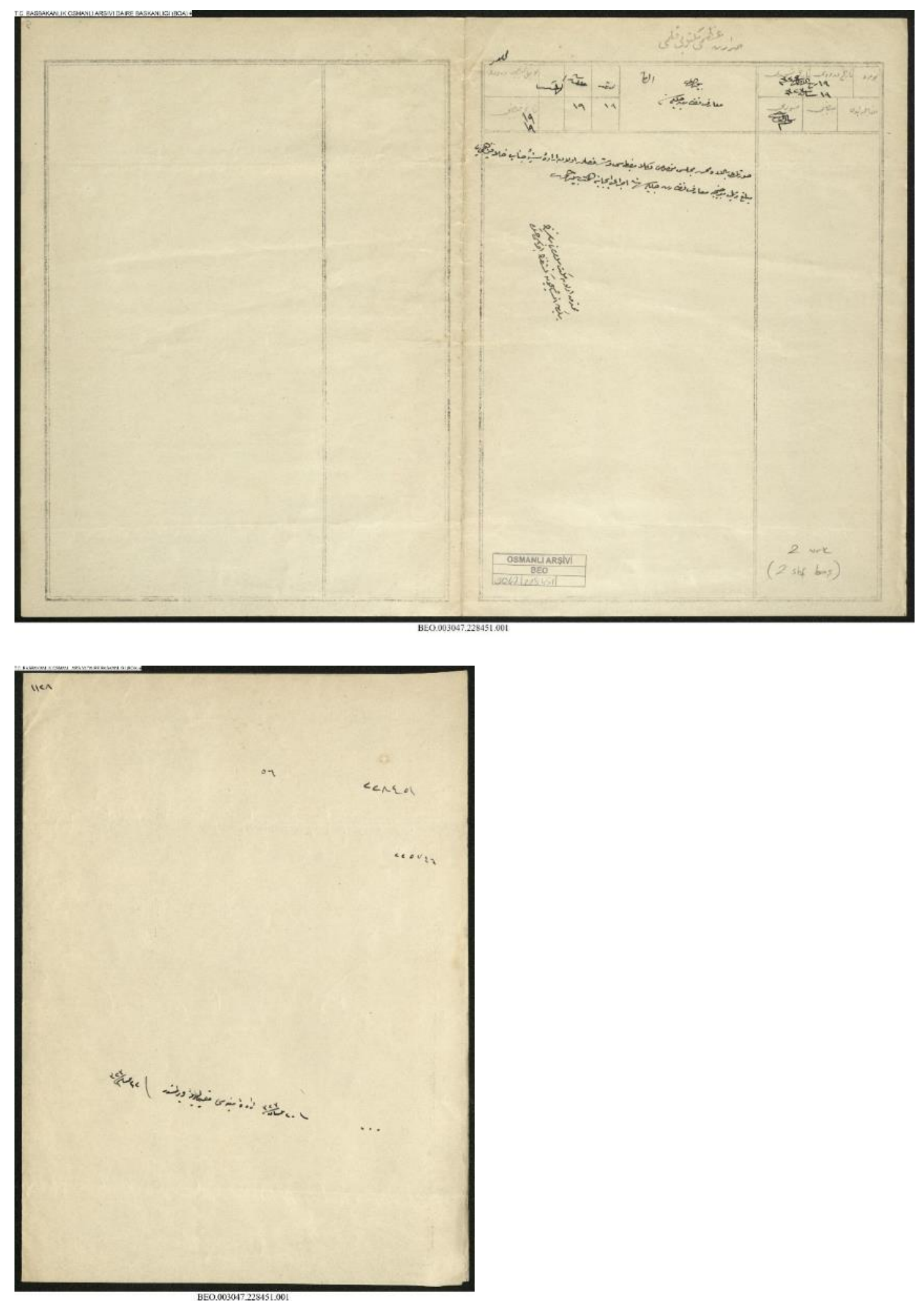

Şekil B.1: BEO (Babıali Evrak Odas1). no:3047, 228451 